\section{A compilation study on the staff definitions and employment problems of the personnel working in the sports services of metropolitan municipalities}

Büyükşehir belediyelerinin spor hizmetlerinde çalışmakta olan personelin kadro tanımları ve istihdam problemlerine yönelik derleme bir çalışma

\author{
Fatih Dinç ${ }^{1}$ \\ Tekin Çolakoğlu ${ }^{2}$ \\ Serkan Kurtipek ${ }^{3}$
}

\begin{abstract}
In this study, the personnel needs of the metropolitan municipalities employed in the sports services, the staff definitions and the situation related to the employment process were determined. It is aimed to examine the problems. Descriptive method is used in the research. The sport services are defined as an assignment in the article 59 of the Constitution of the Republic of Turkey with the expression "The State shall take measures to develop the physical and mental health of Turkish citizens of all ages, and encourage the spread of sports among the masses". Local governments are a form of government that is in direct contact with society, as a public legal entity. The Constitution imposes responsibility on local governments in terms of the implementation of sports services, with these expressions. Furthermore, it is seen that the Municipal Law No. 5393 also imposes various responsibilities and duties. Services shall be provided by municipalities are counted in the subparagraph (a) of the article 14 of Law No 5393. These
\end{abstract}

Özet

$\mathrm{Bu}$ çalışmada büyükşehir belediyelerinin spor hizmetlerinde çalıştırılan personel ihtiyacı, kadro tanımları ve istihdam süreci ile ilgili durum tespit edilmiş ve ortaya çıan sorunların incelenmesi amaçlanmıştır. Araştırmada betimsel yöntemden yararlanılmıştır. Türkiye Cumhuriyeti Anayasasinin 59. Maddesinde; "Devlet, her yaştaki Türk vatandaşlarının beden ve ruh sağlığını geliştirecek tedbirleri alır, sporun kitlelere yayılmasını teşvik eder" ifadesiyle spor hizmetlerini bir ödev olarak tanımlamaktadır. Yerel yönetimler kamu tüzel kişisi olarak topluma doğrudan temas eden bir yönetim biçimidir. Anaysa bu ifadelerle, spor hizmetlerinin yürütülmesi açısından yerel yönetimlere sorumluluk yüklemektedir. Ayrıca 5393 sayllı Belediye Kanununun da çeşitli sorumluluk ve ödevler yüklediği görülmektedir. 5393 sayll kanunun 14. maddesi (a) bendinde yürütmesi gereken hizmetler sayılmıştır. Bunlar arasında gençlik ve spor hizmetlerini yapmak veya yaptırmak görevlerine de yer verilmiştir. $\mathrm{Bu}$ görev ve sorumlulukların yürütülmesi için

\footnotetext{
${ }^{1}$ Ph.D., Student, Gazi University, Institute of Health Sciences, fatihdinc33@gmail.com

2 Assoc. Prof. Dr., Gazi University, Faculty of Sport Sciences, Sports Management Department, ctekin@gazi.edu.tr; tcolakoglu@gmail.com

${ }^{3}$ Ph.D., Gazi University, Faculty of Sport Sciences, Sports Management Department, serkankurtipek@gmail.com
} 
Dinç, F., Çolakoğlu, T., \& Kurtipek, S. (2018). Büyükşehir belediyelerinin spor hizmetlerinde çalışmakta olan personelin kadro tanımları ve istihdam problemlerine yönelik derleme bir çalışma. Journal of Human Sciences, 15(4), 25332552. doi:10.14687/ihs.v15i4.5616

include the task of carrying out or making youth and sports services. Personnel recruitment is needed to carry out these duties and responsibilities. The employment of the municipalities, which are public legal entities, is subject to the Constitution and the law. In the article 128 of the Constitution, there is mentioned that public legal entities are obliged to execute public services shall be carried out by public servants and other public employees. The definition and description of civil servants are made in the Civil Servants Law No. 657. In the study, it was concluded that the terms of reference of the personnel to be stipulated in the sports services carried out metropolitan municipalities and to include their titles in the relevant legislation.

Keywords: Local Governments; Sports; Personnel; Employement.

(Extended English summary is at the end of this document) ise personel istihdamına ihtiyaç duyulmaktadır. Bir kamu tüzel kişisi olan belediyelerin, personel istihdamı Anayasa'ya ve kanuna tabidir. Anayasanin 128. maddesinde, kamu tüzel kişiliklerin yürütmekte yükümlü olduğu kamu hizmetlerini, memurlar ve diğer kamu görevlileri eliyle yürütebileceği hükmü bulunmaktadır. Memurların kim olduğu ve tanımı ise 657 say1l Devlet Memurları Kanununda yapılmaktadır. Çalışmada büyükşehir belediyelerinde yürütülen spor hizmetlerinde istidam edilecek personelin görev tanımı yapılarak ilgili mevzuatta unvanlarına yer verilmesi gerektiği sonucuna ulaşılmıştır.

Anahtar Kelimeler: Yerel Yönetimler; Spor; Personel; İstihdam.

\section{Giriş}

Ülkemizde devletin temel idari görevleri genel yönetim kuruluşları, özelliklede merkez teşkilatı tarafindan yerine getirilmektedir. Ancak her ne kadar hizmetler merkezi idare tarafindan yürütülse de, illerde ve taşralarda yerel yönetimlerle işbirliğini gerekli kılmaktadır. Bu kapsamda devlet kamu hizmetlerini sinıflandırarak mahalli ve ortak nitelik taşıyan yerel düzeydeki hizmetleri gerçekleştirmek için bazı görev, yetki ve sorumluluklarını merkezi idarelerden yerel yönetimlere aktarmaktadır (Kurtipek ve Yenel, 2018, s.445).

Belediyelerin birer yerel yönetim unsuru olduğu bilinmektedir. Yerel yönetim kavramı literatür de bir çok șekilde ortaya konulmuş, bazı kaynaklarda mahalli idare bazılarında yerinden yönetim bir çoğunda ise yerel yönetim şeklinde ifade edilmiştir. Yücel, Atalay ve Korkmaz (2016)'a göre, gün geçtikçe de ortaya çıkan gelişmeler ve ortaya çıkan ihtiyaçların giderilmesi için yeni yönetim metotları geliştirilmiştir. Geliştirilen bu yaklaşımlar toplumla birlikte tekâmül etmiş ve yerel yönetim modeli oluşmuştur. Güngör (2014) ise yerel yönetimler için; "karar organları seçimle oluşturulan, idari ve mali özerkliği ile kamu tüzel kișiliğine sahip" olan idareler ifadesini kullanmıștır.

Ülkemizde yerel yönetimler Anayasa ve ilgili kanunlarla tanımlanmıştır. Ökmen ve Parlak (2010), kuruluşunun, görevlerinin, yetkilerinin ve ilgili tüm konuların yasa çıkarıcı yani T.B.M.M. tarafindan belirlendiği, yönetim sistemi dışında bir unsur olmayan yönetim modeli şeklinde açıklamaktadır. Öktem ve Parlak (2010)'ın dikkat çektiği diğer husus ise yerel yönetimlerin merkezi yönetimle hiyerarşik bir denetim ilişkisi olmadığı ancak uygulamalarının hukuka uygunluğu bakımından merkezce denetlendiğidir.

1924 Anayasasının genel hatlarıyla değinip geçtiği yerinden yönetimler bağlamında ilk önce köy yönetimlerini ele alan Cumhuriyet yönetimi, 1924 tarihli ve 442 sayılı Köy Kanunu ile köyleri tüzel kişi olarak düzenlemiş, ardından da 1930'ların başında kent yönetimlerinin düzenlenmesi çerçevesinde 1580 sayılı belediye yasasını çıkartmıştır (Karakılçık, 2016, s. 135). 
Dinç, F., Çolakoğlu, T., \& Kurtipek, S. (2018). Büyükşehir belediyelerinin spor hizmetlerinde çalışmakta olan personelin kadro tanımları ve istihdam problemlerine yönelik derleme bir çalışma. Journal of Human Sciences, 15(4), 25332552. doi:10.14687/ihs.v15i4.5616

Günümüzde yürürlükteki 1982 yılında kabul edilen Türkiye Cumhuriyetinin Anayasası yerel yönetimleri; "Mahalli idareler; il, belediye veya köy halkının mahalli müşterek ihtiyaçlarını karşılamak üzere kuruluş esasları kanunla belirtilen ve karar organlanı, gene kanunda gösterilen, seçmenler tarafindan seçilerek oluşturulan kamu tüzelkişileridir." ifadeleriyle tanımlamıştır (Türkiye Cumhuriyeti Anayasası ve Türkiye Büyük Millet Meclisi İçtüzügü, 2015, Md. 127, s. 88).

Weber (2012), Şehir (Il) ile ilgili, "sakinlerinin öncelikle tarımdan ziyade alışveriş ve ticaretle geçindiği, bir koloniyi kapsamlı olarak biçimlendiren, öyle ki oturanların karşlıklı kişisel tanışıklığ1 bulunan yakın olarak aralıklı hanelerin planlandığı geniş bir bölge" olduğunu söylemiştir. Ülkemizde devletin yani merkez yönetimin taşradaki ana unsuru olan il, bir yerel yönetim birimi olan İl Özel İdaresinin sınırlarını belirler (Şengül, 2014, s. 47).

Ortaylı (1985), "Ülkemizde yerel yönetim; Bab-1 Âli’nin imparatorluğu etkin bir biçimde kontrol etmeye giriştiği ve kısmen bunu başardığı bir dönemde doğduğunu" söylemektedir. Osmanlı'da ulaşım yollarının ve üretim merkezlerinin gelişmesi ile ticaretin büyümesi, özellikle de liman yerleşimlerinin büyümesi belediye idarelerinin kurulmasında etkili olmuştur (Ortaylı, 1985, s. 29-32).

Ülkemizde belediye kurulması girişiminin ilk kez İstanbul'da 1855 yllında gerçekleşmiştir. Buna göre başında hükümetçe atanan bir Şehremin olduğu 12 kişilik şehir meclisi, batı ülkeleri şehirlerinde yapılan işlerin benzerlerini yapacaktı. Oluşturulan İntizami Şehir Komisyonu Belediye Nizamnamesi hazırlayarak İstanbul'da semt semt belediye yönetimi kurulmasını teklif etti. Böylece 1958 y1lında Galata ve Beyoğlu bölgelerini kapsayan Altıncı Belediye Dairesi kuruldu. 1869 belediyelerin İstanbul'un tamamına yaygınlaştırılmasına karar verilmiştir. 1876 anayasasında belediyelerin İstanbul ve taşrada seçimle iş başına gelecek meclisler eliyle yönetilmesi karara bağlanmıştır. Bu durum Cumhuriyet döneminde de devam etmiş ancak 1930 yllında 1580 sayılı Belediye Kanunu çıkınca hükmü ortadan kalkmıştır (Tortop, 1994, s.1-4).

İnsanların bir arada yaşama ihtiyacı ile kendiliğinden meydana gelmiş en eski yerel yönetim birimi olan köy Osmanlı'da 1864 Vilayet Nizamnamesiyle ilk kez yasal bir metinde yer bulmuştu. (Ökmen \& Parlak, 2010, s. 275-276). Cumhuriyet’ten sonra 1924 tarihli ve 442 sayıll Köy Kanunu çıkarılmış, köylerin tüzel kişilikleri düzenlenmiş ve hala yürürlüktedir (Karakılçık, 2016, s. 135).

Osmanlı'da Tanzimat'tan sonra battya açlma çabalarının sonucu olarak ortaya çıan belediye (Şahin, 2014, sf. 94) devlet teşkilatının tamamlayıcllı̆ı̆ görevi üstlenmektedir (Konur, 2017, s. 6). Bu dönemden sonra teşkil edilmeye başlayan belediyelerin bu günkü yapıya kavuşmaları cumhuriyetten sonraki dönemde mümkün olmuştur. 1970’li ylllarda önemi iyice belirginleşen belediyeler 2000'lerden sonra Avrupa Birliği ile yapılan müzakereler çerçevesinde yeniden yapılandırılmış ve mevcut hale ulaşmıştır (Karakılçık, 2016, s. 159).

Ülkemizde Belediyeler, Türk kamu yönetimindeki reformlarla birlikte Temmuz 2005 tarihinde kabul edilen 5393 saylı belediye kanunu kapsamında kurularak, organlarını ve yönetimleri oluşturulan yerel birimlerdir. Aynı kanun kapsamında belediyelerin görev, yetki ve sorumlulukları ile çalışma usul ve esasları belirlenmiştir. Büyükşehir belediyeleri ise temmuz 2004 tarihinde yürürlüğe giren 5216 saylı büyükşehir belediyesi kanunu ile hukukî statüsünü düzenlenmiş, hizmetlerin plânlı, programl, etkin, verimli ve uyum içinde yürütülmesini sağlamak amacıyla bir hukuki çerçeve çizilmiştir.

Dolayısıyla bu araştırmada büyükşehir belediyelerinin spor hizmetlerinde çalıştırılan personel ihtiyacı, kadro tanımları ve istihdam süreci ile ilgili durum tespiti yapılmıss ve ortaya çıkan sorunların incelenmesi amaçlanmıştır.

\section{Büyükşehir Belediyesi}

Metropolis, metropoliten, metropol, anakent şeklinde de ifade edilen büyükşehir, yunancadaki metro (ana, asıl) ve polis (kent) kelimelerinin bir araya getirilmesiyle oluşturulan metropolis kavramının karşılığıdır. Aslında ortaya çıktığı dönemlerde bu kelime antik yunan kent devletlerini tanımlamaktaydı. Günümüzde kullanılan anlamına ulaşması ise 19. yüzyılda en üst 
Dinç, F., Çolakoğlu, T., \& Kurtipek, S. (2018). Büyükşehir belediyelerinin spor hizmetlerinde çalışmakta olan personelin kadro tanımları ve istihdam problemlerine yönelik derleme bir çalışma. Journal of Human Sciences, 15(4), 25332552. doi:10.14687/ihs.v15i4.5616

seviyeye ulaşan sanayileşme dönemine dayandırmak mümkündür. Sanayileşme sonucu meydana gelen kente olan göçlerden dolayı büyük yerleşim merkezleri meydana gelmiş, bu merkezlerin de büyükşsehir olarak tanımlanması alışkanlık halini almıştır (Şahin, 2014, s. 157). Sanayileşme ve benzeri sebeplerden dolayı hızlı bir kentleşme süreci yaşanmış, bunun sonucunda büyüyen kent yaşamına yeni yönetim modelleri arayışlarına gidilmiştir. Kentlerin düzen ve estetiğinin korunması amaçlanmıştur (Keleş ve Yavuz, 1983 s. 268).

Toprak’a (2006) göre, Milli Güvenlik Konseyi tarafindan, ülkemizde büyükkent yönetim uygulamasına geçiş açısından dikkate değer olarak gördüğü bir adım atılmıştır. Konsey 11 aralık 1980 tarihinde alınan 34'nolu karara ile yoğun göç ve nüfus artışından dolayı büyükkentlerin çevresinde kurulan belediyelerin sıkı̈önetim komutanlarının emrinde merkez belediyelere bağlanmasına istemiştir (Toprak, 2006, s. 204). Ancak günümüzde yürürlükte olan 5216 sayll büyükşehir belediye kanunu, 2004 tarihinde çıkarllarak büyükşehir belediyelerinin yönetim biçimi belirlemiştir. Son haline kavuşma sürecinde en önemli konulardan birisi 2012 yllında kabul edilen 6360 numaralı kanundur. 6360 sayılı On Dört İlde Büyükşehir Belediyesi ve Yirmi Yedi İlçe Kurulması İle Bazı Kanun ve Kanun Hükmünde Kararnamelerde Değişiklik Yapılmasına Dair Kanun çerçevesinde yapılan değişiklik ile 5216 sayılı büyükşsehir belediyesi kanununda yapılan değişiklik, büyükşehir belediyelerinin sınırları il mülki sınır olarak belirlenmiştir. Bu kanuna göre ülkemizde büyükşehir belediye sayısı 30'a yükseltilmiş ve büyükşehir belediye yönetiminin hukuki statüsüne düzenleme getirilmiştir. Bu durum büyükşehirlerde yeni bir yönetim anlayışını gündeme getirmiştir. Daha önce yalnızca il merkezinde bulunan alt birim belediyelerin yani merkez ilçe belediyelerinin koordinasyonundan sorumluyken tüm il sınırları içerisindeki tüm belediyelerin koordinasyonundan sorumlu hale gelmiştir.

Tablo 1. Büyükșehir Belediyelerinin Kuruluş Tarihi (Keleş, 2012 s.330)

\begin{tabular}{ll}
\hline Kuruluş Yilı & Büyükşehir Belediyeleri \\
\hline 1984 & İstanbul, Ankara, İzmir \\
\hline 1986 & Adana \\
\hline 1987 & Bursa, Gaziantep, Konya \\
\hline 1988 & Kayseri \\
\hline 2093 & Antalya, Diyarbakır, Erzurum, Eskişehir, İzmit, Mersin, Samsun \\
\hline 2012 & Adapazarı \\
\hline 2013 & $\begin{array}{l}\text { Aydın, Balıkesir, Denizli, Hatay, Kahramanmaraş, Malatya, Manisa, Mardin, Muğla, } \\
\text { Şanlıurfa, Tekirdağ, Trabzon, Van }\end{array}$ \\
\hline
\end{tabular}

(* 6360 Sayllı On Dört Ilde Büyükşehir Belediyesi ve Yirmi Yedi Ilçe Kurulmasi Ile Bazi Kanun Ve Kanun Hükmünde Kararnamelerde Değissiklik Yapilmasina Dair Kanun, Md. 1)

5216 saylı büyükşehir belediyesi kanununda yer alan işleri ve ödevleri yürütmek için kadroya ihtiyaç bulunmaktadır. İtalyanca (quadro) kökenli bir kelime olan kadro Türk Dil Kurumu'nun internet sitesinde "bir kamu kuruluşunun, bir işletmenin, denetim veya yönlendirme işlerini gerçekleştirenler ve bunların taşıdığı ödev, yetki ve sorumlulukların hepsi" ve "bir işte görev alan kişi veya kişiler, ekip" şeklinde tanımlanmıştır. (Türk Dil Kurumu, 2018). Belediyelerde kadro işlemleri geçmişte 190 sayll kanun hükmünde kararnamelerle yürütülmekteyken 2004 yllında çıkarılan 5272 sayll belediyeler kanunu ile bu yetki kendi meclislerine verilmiştir. Buna göre kadro işlemleri 2007 yıllnda İçişleri Bakanlığ1 ve Devlet Personel başkanlığınca çıkarılan Belediyeler ve Bağlı Kuruluşlar İle Mahalli İdare Birlikleri Norm Kadro İlke ve Standartlarına Dair Yönetmeliğe göre göre yürütülmektedir (Güngör, 2014, s.59). Bu yönetmelikle birlikte yayınlanan ve 2016 yılındaki değişiklikle halen yürürlükte olan belediye ve bağlı kuruluşları ile mahalli idare birlikleri tasnif cetvellerinde büyükşehir belediyeleri, il ve ilçe belediyeler nüfuslarına göre tasnif edilmişlerdir. 
Dinç, F., Çolakoğlu, T., \& Kurtipek, S. (2018). Büyükşehir belediyelerinin spor hizmetlerinde çalışmakta olan personelin kadro tanımları ve istihdam problemlerine yönelik derleme bir çalışma. Journal of Human Sciences, 15(4), 25332552. doi:10.14687/ihs.v15i4.5616

Belediye ve Bağı Kuruluşları İle Mahalli İdare Birlikleri Norm Kadro İlke ve Standartlarına Dair Yönetmeliğin Ek-1 Belediye ve Bağlı Kuruluşları İle Mahalli İdare Birlikleri Tasnif Cetvellerine göre tüm belediyeler (büyükşehir, il, ilçe ve belde) nüfusa göre sınıflandırılmıştır. Bu sınıflandırmaya göre büyükşehir ve büyükşehir ilçe belediyeleri aşağıdaki şekilde tasnif edilmiştir.

Tablo 2. (A) Grubu: Büyükşehir Belediyeleri Tasnif Cetveli

\begin{tabular}{lll}
\hline Grup Kodu & Nüfus & Büyükşehir Sayıs1 \\
\hline A-1 & $0-999999$ & 10 \\
\hline A-2 & $1000000-1999999$ & 13 \\
\hline A-3 & $2000000-2999999$ & 4 \\
\hline A-4 & $3000000-4999999$ & 1 \\
\hline A-5 & $5000000-7499999$ & 1 \\
\hline A-6 & 7500000 ve ÜZERİ & 1 \\
\hline
\end{tabular}

(Belediye ve Bağli Kuruluşlari Ile Mahalli Idare Birlikleri Norm Kadro Ilke ve Standartlarina Dair Yönetmelik Ek-1)

Tablo 3. (C) Grubu: Büyükşehir İlçe Belediyeleri Tasnif Cetveli

\begin{tabular}{lll}
\hline Grup Kodu & Nüfus & İlçe Belediye Sayıs \\
\hline C-2 & $10000-14999$ & 40 \\
\hline C-3 & $15000-19999$ & 40 \\
\hline C-4 & $20000-29999$ & 34 \\
\hline C-5 & $30000-49999$ & 48 \\
\hline C-7 & $50000-74999$ & 53 \\
\hline C-8 & $75000-99999$ & 54 \\
\hline C-9 & $100000-149999$ & 35 \\
\hline C-10 & $150000-199999$ & 30 \\
\hline C-12 & $200000-249000$ & 41 \\
\hline C-13 & $250000-299999$ & 28 \\
\hline C-14 & $300000-399999$ & 27 \\
\hline C-15 & $500000-499999$ & 15 \\
\hline C-16 & $600000-599999$ & 13 \\
\hline C-17 & $700000-699999$ & 25 \\
\hline C-18 & $800000-899999$ & 6 \\
\hline C-19 & $900000-999999$ & 7 \\
\hline B 1000000 ve ÜZERI & 9 \\
\hline
\end{tabular}

(Belediye ve Bağli Kuruluşlari Ile Mahalli Idare Birlikleri Norm Kadro Ilke ve Standartlarina Dair Yönetmelik Ek-1)

\section{Belediyelerde Spor Hizmetleri}

5393 sayll belediye kanunun 14. maddesinin (a) bendinde görev, yetki ve sorumluluklarını tanımlarken gençlik ve spor hizmetlerinden bahsetmektedir. Bu maddeye göre, belediyelerin; halkın müşterek ihtiyaçları olması şartı ile birçok hizmet alanı yanı sıra gençlik ve spor hizmetlerinin yürütülmesi görevi verilmektedir. Ayrıca yasa koyucu, aynı maddenin (b) bendinde 12.11.2012 tarihinde yapılan bir değişiklikle "Gerektiğinde, sporu teşvik etmek amacıyla gençlere spor malzemesi verir, amatör spor kulüplerine ayni ve nakdî yardım yapar ve gerekli desteği sağlar, her türlü amatör spor karşılaşmalan düzenler, yurt içi ve yurt dışı müsabakalarda üstün başarı gösteren veya derece alan öğrencilere, sporculara, teknik yöneticilere ve antrenörlere belediye meclisi karariyla ödül verebilir. Gıda bankacıllğı yapabilir" ibareleri eklenmiş. Böylece yapacağı hizmetleri daha ayrıntılı bircimde tanımlamıştır (5393 sayılı Belediye Kanunu, Md. 14).

5216 sayılı büyükşehir belediye kanunun 7. maddesinde büyükşehir belediyesinin görev ve sorumlulukları sıralanmaktadır. Burada yer alan (m) bendinde "Büyükşehir'in bütünlügüne hizmet eden sosyal donatılar, bölge parkları, hayvanat bahçeleri, hayvan barınakları, kütüphane, müze, spor, 
Dinç, F., Çolakoğlu, T., \& Kurtipek, S. (2018). Büyükşehir belediyelerinin spor hizmetlerinde çalışmakta olan personelin kadro tanımları ve istihdam problemlerine yönelik derleme bir çalışma. Journal of Human Sciences, 15(4), 25332552. doi:10.14687/ihs.v15i4.5616

dinlence, eğlence ve benzeri yerleri yapmak, yaptırmak, işletmek veya işlettirmek; gerektiğinde amatör spor kulüplerine nakdî yardım yapmak, malzeme vermek ve gerekli desteği sağlamak, amatör takımlar arasında spor müsabakaları düzenlemek, yurt içi ve yurt dışı müsabakalarda üstün başarı gösteren veya derece alan sporculara, teknik yönetici, antrenör ve öğrencilere belediye meclis kararıyla ödül vermek.” ifadeleri yer bulmuştur (5216 sayılı Büyükşehir Belediye Kanunu, Md. 7).

5393 sayılı belediye kanunun 14. maddesinin devamında ise, 12.07 .2013 tarihinde bu günkü şeklini alan bir değişiklikle, belediyelerin sporu teşvik etmek amacıyla yapacakları nakdi yardıma bir sınırlama getirilmiştir. Buna göre bir önceki yll genel bütçe vergi gelirlerinden belediyeleri için tahakkuk eden miktarın; büyükşehir belediyeleri için binde yedisini, diğer belediyeler için binde on ikisini geçemeyeceği belirtilmiştir (14. Madde). Belediye meclisinin görev ve yetkilerini düzenleyen 18. maddenin $\mathrm{p}$ bendinde yurtiçinde ve içişleri bakanlığının iznine bağlı olarak yurt dışındaki belediyelerle ekonomik ve sosyal ilişkileri geliştirmek amacıyla kültür, sanat ve spor gibi alanlarda faaliyet ve projeler gerçekleştirilmesine karar vermesine izin vermektedir (5393 sayıll Belediye Kanunu, Md. 18)

5393 sayll belediye kanunu ve 5216 sayılı büyükşsehir belediye kanununda spor hizmetleri ile ilgili yüklenen sorumluluk ve ödevlerin yerine getirilebilmesi için işi yürütmek üzere görevlendirilecek personele ihtiyaç duyulmaktadır. Hem yerel yönetimlerde bu ihtiyacın giderilebilmesi hem de ülke genelinde ihtiyaç duyulan kurum ve kuruluşlarda görev alabilecek personelin yetiştirilmesi için yüksek öğretim kurumlarına bağlı beden eğitimi ve spor yüksekokulları ya da spor bilimleri fakülteleri eğitim ve öğretim faaliyetleri yürütmektedir. Bu okullar 4 anabilim dalına ayrrlmıştır. Bunlar beden eğitimi öğretmenliğ̣i bölümü, spor yöneticiliği bölümü, antrenörlük bölümü ve rekreasyon bölümleridir.

$\mathrm{Bu}$ personel ihtiyacını giderebilmek ancak 22.2.2007 tarihinde yürürlüğe giren belediye ve bağlı kuruluşları ile mahalli idare birlikleri norm kadro ilke ve standartlarına dair yönetmelikle mümkün olmaktadır.

\section{Spor Yöneticisi}

Sunay spor yöneticisini, "Beden Eğitimi ve Spor alanlarında amaçlanan hedeflere ulaşılabilmesi için spor kurumlarında çalışan insanları teşkilatlandıran, emirler veren, grup çalışmalarını aynı amaca yönlendirip düzenleyen, sorumluluğu üstlenen ve işleyişi denetleyen" kişi olarak tanımlamaktadır (Sunay, 2009, s. 177).

Spor kulüpleri tüzel kişilerini idare eden gerçek kişileri spor yönetici olarak tanımlayan Genç (1998), kulüplerin yönetim işini üstlenmiş, kulübün hedefleri gerçekleştiren, profesyonel yani ücret alan ya da fahri kişiler olduklarını belirtmiştir.

\section{Antrenör}

Konter (1996), antrenörün sporcuların duygusal ve sosyal, zihinsel ve fiziksel kapasitelerinin hedeflere göre geliştirilmesine yardımcı olduğunu belirtmiştir. Ayrıca antrenmanın bilimsel amaçlarını yerine getirerek gerçekleştiren özel eğitim almış kişiler olduğunu söylemektedir.

Sevim (2006) ise; "Teknisyen olarak gerekli bilgileri bilimin 1şığında sporcunun başarısı için kullanan, daha sonra bu bilgileri spor becerileri ve stratejiler ile birleştiren ve farklı mizaçlardaki insanlara uygulayabilen kişiler" olarak tanımlamaktadır. Ziyagil (2013), antrenörlük kavramını tanımlarken ise şu ifadeleri kullanmaktadır; "sporcunun potansiyelini en üst düzeyde kullanarak başar1ya ulaşması için sportif çalışmalara, eğitim ve sosyal yaşamda rehberlik, teşvik, yönetim, geribildirim ve yardım sağlanmasına antrenörlük denir.” Konter (1996)'e göre, sporcunun kazandığ1 yeni becerilerde uzmanlaşması, başka sporcularla birlikte yarışması, bu süreçte zevk alması ve kendisini değerli hissetmesine yardımcı olan antrenör başarılıdır. 
Dinç, F., Çolakoğlu, T., \& Kurtipek, S. (2018). Büyükşehir belediyelerinin spor hizmetlerinde çalışmakta olan personelin kadro tanımları ve istihdam problemlerine yönelik derleme bir çalışma. Journal of Human Sciences, 15(4), 25332552. doi:10.14687/ihs.v15i4.5616

\section{Rekreasyon Uzmanı}

Literatürde çeşitli şekillerde tanımlanmış olan rekreasyon kavramının ortak yönlerini bir araya getiren Ardahan'a (2016) göre insanların hür iradeleriyle grup olarak ya da tek başlarına, serbest zamanlarında, eğlenmek, fizik ve ruh açısından tazelenmek ve dinlenmek amaçlı yaptıkları etkinliklerdir. Rekreasyon, insanın yaşamında yapması zorunlu olan (örneğin yemek, uyumak, çalışmak vb.) durumlar dışında kalan serbest zamanda uygulanan aktivitelerdir. Serbest zaman ise işin zorluklarından ayrı olarak, rahatlama, eğlence, bilgi kazanımı ve sosyal katılımı artırmak amacı taşıyan, yaratıcı kapasitenin özgür etkinliğidir (Tekin, 2016, s. 48).

Hareketliliğe uyum sağlayabilecek bedensel yeterlilikte, tanımda geçen konularda yani rekreasyon alanlarında bilgi ve beceriye sahip, iletişim becerileri güçlü, araşturmacı, çağdaş ve teknolojik gelişmeleri takip edebilen kişilere ise rekreasyon uzmanı denilmektedir. (Yıldırım, 2018)

Rekreasyon Çalışmaları ve Araştırmaları Derneğinin 18-19 Mart 2016 yılında gerçekleştirdiği rekreasyon çalıştayı tutanaklarında rekreasyon uzmanlığı için iş tanımı önerisinde bulunulmuştur. Buna göre; spor, sağlık, kültür, sanat ve sosyal programlarnn/etkinlik/aktivitelerin üretimi, danışmanlı̆̆ ve yönetimi (planlanması, örgütlenmesi, uygulanması koordinasyonu ve denetlenmesi) süreci fonksiyonlarını içerir (Rekreasyon Çalışmaları ve Araştırmaları Derneği, 2016)

İstihdam alanları olarak rekreasyon uzmanları devlet kademesinde Spor Hizmetleri Genel Müdürlüğ̈’nün bünyesinde, belediyelerde, kamu kuruluşlarında, özel idarelerde, sosyal tesislerde, spor kulüplerinde okul ve üniversitelerde, özel sektörde, turizm sektöründe, spor ve rehabilitasyon merkezlerinde, spor komplekslerinde, otellerin wellness ve fitness Salonlarında iş olanağ1 bulabilmektedir (Yıldırım, 2018)

Kamu hizmetleri görevlileriyle ilgili Anayasanın 128. maddesi; "Devletin, kamu iktisadi teşebbüsleri ve diğer kamu tüzel kişilerinin genel idare esaslarına göre yürütmekle yükümlü oldukları kamu hizmetlerinin gerektirdiği asli ve sürekli görevler, memurlar ve diğer kamu görevlileri eliyle görülür" diyerek kamu hizmetleri yürüten personeli Anayasal güvence altına almıştır (Türkiye Cumhuriyeti Anayasası ve Türkiye Büyük Millet Meclisi İçtüzügü, 2015, Md. 128, s. 89). Belediyelerin personel ile ilgili işleri de 5393 sayll belediye kanununda tanımlanmış ve sınırlandırılmıştır. Bu kanuna göre belediyelerde çalışabilecek personel devlet memuru kanununa bağlı bir şekilde istihdam edilebilmektedir. 657 sayılı devlet memurları kanununun 4. maddesinde 4 tip personelden bahsedilmektedir. Buna göre kamu hizmetleri; memurlar, sözleşmeli personel, geçici personel ve işçiler eliyle gördürülür. Türkiye'de belediyeler yasa ile kurulan kamu tüzel kişisidir (5393 sayılı Belediye Kanunu, Md. 3). Dolayısıyla belediyeler burada ifade edilen 4 tip personel dişında personel istihdam edemezler. Kanunun 5. maddesinde "bu kanuna tabi kurumlar, dördüncü maddede yazılı dört istihdam şekli dışında personel çalıștıramazlar" ifadesi yer alsa da 696 sayılı Kanun Hükmünde Kararnamenin 17. maddesiyle 657 sayll devlet memurları kanunun 4. maddesi (c) bendinde yer alan geçici personel tanımı kaldırıldığından dolayı yürürlükte olan 3 istihdam şekli kast edilmektedir.

İstihdam süreçlerinde naklen ve açıktan atama usullerinin de uygulanabildiği görülmektedir. Bu usule göre herhangi bir kurum ve kurulușta memur olarak görev yapan bireyin belediyelerde ya da bağlı kuruluşlarda uygun kadrolarda istihdam edilebilmesine naklen atama denir. Daha önce kamu kurum ve kuruluşlarında memur olarak çalıstığ halde buradan istifa ederek ayrilmış, bir müddet sonra tekrar memur olarak görev yapmak istemesi sonucu belediye bünyesinde uygun görülen bir kadroya atanmasına da açıktan atama denilmektedir (Güngör, 2014, s.95).

\section{Memur}

Arapça "Emr” kelime kökünden türetilmiş “emir alan kişi” anlamına gelen memur, kamu teşkilatlarına bağlı olarak görev yapan, atanarak hizmete alınan ve devletçe verilen maaş ile hayatını idame ettiren kamu hizmeti yürütücüsüdür (Aslan, 2014, s.14). Weber (2012) ise memuru, serbest sözleşmelerde olduğu gibi ortak hizmet değişiminin aksine garanti bir geçim sağlaması karşıllğında kurumun amacına bağlılık görevini kabul etmek olarak tanımlamaktadır. 
Dinç, F., Çolakoğlu, T., \& Kurtipek, S. (2018). Büyükșehir belediyelerinin spor hizmetlerinde çalışmakta olan personelin kadro tanımları ve istihdam problemlerine yönelik derleme bir çalışma. Journal of Human Sciences, 15(4), 25332552. doi:10.14687/ihs.v15i4.5616

Ülkemizde memur tanımı ve sınıflandırilması, temmuz 1965 yılında çıkarılan ve günümüze kadar birçok değişikliğe uğrayarak gelen ve halen yürürlükte olan 657 sayılı devlet memurları kanunu ile belirlenmektedir. Bu kanunun 4. maddesine göre; "kuruluş biçimine bakılmaksızın, devlet ve diğer kamu tüzel kişiliklerince genel idare esaslarına göre yürütülen asli ve sürekli kamu hizmetlerini ifa ile görevlendirilenler" memur olarak tanımlanmaktadır.

Memurluk 657 sayılı devlet memurları kanununda tanımlanmış ve sınıflandırılmıştır. Kişiler devlet memuru olabilmeleri için bu kanunun 48. maddesinde belirtilen genel şartları taşıyor olması gerekmektedir. Ayrıca istihdam edilecek kurumlarca 48. maddenin (b) bendinde belirtilen özel şartları da taşıyor olması istenebilmektedir. Türk vatandaşı olan ve 18 yaşını tamamlayanlar devlet memuru olabilirken istisna olarak 15 yaşını doldurmuş ve "kendi isteği ve velisinin rızasıyla mahkemece ergin kilınan" (4721 sayılı Türk Medeni Kanun, Md. 12) ve bir meslek ve sanat okulunu bitirenler de memurluk görevini yürütebilmektedirler. Bu şartları taşıyan ve 50 . maddede belirtildiği üzere açlacak devlet memurluğu sinavlarına (KPSS) giren ve sinavı kazananlar ancak devlet memuru olarak atanabilmektedirler. Bu sınav, Devlet Personel Başkanlığı tarafindan belirlenen usul ve esaslara göre yapilır. Bunun dişında sınavsız personel alımları da yine devlet personel başkanlığınca hazırlanacak genel bir yönetmeliğe göre yapılmaktadır.

Kurumlarda genel politika tespiti, araştırma, planlama, programlama, yönetim ve denetim gibi işlerde görevli ve yetkili olanlar da memur sayılacakları belirtilmektedir. Bu durumdakilerin memur olarak sayılmasının sebebi ise bazı kamu hizmetlerini kamu hukukuna dayalı yetkileri kullanarak yürütmelerinden kaynaklanmaktadır (Devlet Personel Başkanlığı, 2018)

657 numaralı Devlet Memuru Kanunun 36 maddesinde memurlar belirli sınıflara ayrılmıştır. $\mathrm{Bu}$ durum aşağıda tablo halinde gösterilmiştir.

Tablo 4. 657 Devlet Memuru Kanunu Kapsamına Giren Memurların Sınıflarını Gösteren Tablo

\begin{tabular}{|c|c|}
\hline Siniflar & Kapsamlar \\
\hline $\begin{array}{l}\text { 1- Genel İdare } \\
\text { Hizmetleri Sinıfi }\end{array}$ & $\begin{array}{l}\text { Yönetim, icra, büro ve benzeri hizmetler ve bu Kanunla tespit edilen diğer sinıflara girmeyen } \\
\text { memurlar }\end{array}$ \\
\hline $\begin{array}{l}2 \text { - Teknik Hizmetler } \\
\text { Sinifi }\end{array}$ & $\begin{array}{l}\text { Yüksek mühendis, mühendis, yüksek mimar, mimar, jeolog, hidrojeolog, hidrolog, jeofizikçi, } \\
\text { fizikçi, kimyager, matematikçi, istatistikçi, yöneylemci (Hareket araştırmacısı), matematiksel } \\
\text { iktisatc1, ekonomici ve benzeri ile teknik öğretmen okullarından mezun olup da, öğretmenlik } \\
\text { mesleği dışında teknik hizmetlerde çalışanlar, Mimarlık ve Mühendislik Fakültesi veya } \\
\text { bölümlerinden mezun şehir plancisı, yüksek şehir plancıs1, yüksek Bölge Plancısı, } 3437 \text { ve } \\
9 / 5 / 1969 \text { tarih } 1177 \text { sayılı Kanunlara göre tütün eksperi yetiştirilenler ile müskirat ve çay } \\
\text { eksperleri, fen memuru, yüksek tekniker, tekniker teknisyen ve emsali teknik unvanlara sahip } \\
\text { olup, en az orta derecede mesleki tahsil görmüş bulunanlar }\end{array}$ \\
\hline
\end{tabular}

3 - Sağlık Hizmetleri Ve Sağlık hizmetlerinde (Hayvan sağlığı dahil) mesleki eğitim görerek yetişmiş olan tabip, diş Yardımcı Sağlık tabibi, eczac1, veteriner hekim gibi memurlar ile bu hizmet sahasında çalışan yüksek öğrenim Hizmetleri Sınıfı görmüş fizyoterapist, tıp teknoloğu, ebe, hemşire, sağlık memuru, sosyal hizmetler mütehassısı, biyolog, psikolog, diyetçi, sağlık mühendisi, sağlık fizikçisi, sağlık idarecisi ile ebe ve hemşire, hemşire yardımcısı, (Fizik tedavi, laboratuvar, eczacı, diş anestezi, röntgen teknisyenleri ve yardımcıları, çevre sağlığı ve toplum sağlığ1 teknisyeni dahil) sağlık savaş memuru, hayvan sağlık memuru ve benzeri sağllk personeli

\begin{tabular}{|c|c|}
\hline $\begin{array}{l}4 \text { - Eğitim Ve Öğretim } \\
\text { Hizmetleri Sınıfi }\end{array}$ & Eğitim ve öğretim vazifesiyle görevlendirilen öğretmenler \\
\hline $\begin{array}{l}5 \text { - Avukatlik Hizmetleri } \\
\text { Sinifi }\end{array}$ & $\begin{array}{l}\text { Avukatlık ruhsatına sahip, baroya kayıtlı ve kurumlarını yarg1 mercilerinde temsil yetkisini haiz } \\
\text { olan memurlar }\end{array}$ \\
\hline 6 - Din Hizmetleri Sinifi & Çeşitli derecelerde dini eğitim görmüş olan ve dini görev yapan memurlar \\
\hline $\begin{array}{l}\text { 7 - Emniyet Hizmetleri } \\
\text { Sinifi }\end{array}$ & $\begin{array}{l}\text { Çarşı ve mahalle bekçisi, polis, komiser muavini, komiser, başkomiser emniyet müfettişi, polis } \\
\text { müfettişi, emniyet amiri ve emniyet müdürü ve emniyet müdürü sıfatını kazanmış emniyet } \\
\text { mensubu memurlar }\end{array}$ \\
\hline $\begin{array}{l}8 \text { - Jandarma Hizmetleri } \\
\text { Sinifi }\end{array}$ & Genel Komutanlı̆g kadrolarında bulunan subay, astsubay ve uzman jandarmalar \\
\hline $\begin{array}{l}9 \text { - Sahil Güvenlik } \\
\text { Hizmetleri Sınıfi }\end{array}$ & Sahil Güvenlik Komutanlığı kadrolarında bulunan subay ve astsubaylar \\
\hline
\end{tabular}


Dinç, F., Çolakoğlu, T., \& Kurtipek, S. (2018). Büyükșehir belediyelerinin spor hizmetlerinde çalışmakta olan personelin kadro tanımları ve istihdam problemlerine yönelik derleme bir çalışma. Journal of Human Sciences, 15(4), 25332552. doi:10.14687/ihs.v15i4.5616

10 - Yardımcı Hizmetler Kurumlarda her türlü yazı ve dosya dağıtmak ve toplamak, müracaat sahiplerini karşılamak ve Sınıfi yol göstermek; hizmet yerlerini temizleme, aydınlatma ve isıtma işlerinde çalışmak veya basit iklim rasatlarını yapmak; ilaçlama yapmak veya yaptırmak veya tedavi kurumlarında hastaların ve hastanelerin temizliği ve basit bakımı ile ilgili hizmetleri yapmak veya kurumlarda koruma ve muhafaza hizmetleri gibi anahizmetlere yardımc1 mahiyetteki görevlerde her kurumun özel bünyesine göre ve yine bu mahiyette olmak üzere ihdasına lüzum gördüğü yardımcı hizmetleri ifa ile görevli bulunanlardan 4 üncü maddenin (D) bendinde tanımlananların dışında kalanlar

11 - Mülki İdare Amirliği Valiler ve kaymakamlar ile bu sıfatları kazanmış olup İçişleri Bakanlığı merkez ve iller Hizmetleri Sınıfı kuruluşunda çalışanlar ve maiyet memurlar

12 - Milli İstihbarat Milli İstihbarat Teşkilatı kadrolarında veya bu teșkilat emrinde çalıştırılanlardan özel Hizmetleri Sınıfi kanunlarında gösterilen veya Cumhurbaşkanınca tespit edilen görevleri ifa edenler

(657 sayılı Devlet Memurlan Kanunu, Md. 36)

Belediyelerde istihdam edilen 657 sayılı kanuna tabi memur unvanları olarak çeşitli derece ve unvanlarda, 1 adet avukatlik hizmetleri, 1 adet din hizmetler, 239 adet genel idari hizmetler, 34 adet sağlık hizmetleri, 36 adet teknik hizmetler, 17 adet de yardımcı hizmetler şeklinde sınıflandırılmış kadro bulunmaktadır. Buna göre spor hizmetlerinde görevlendirilen tüm personel genel idari hizmetler kapsamında değerlendirilmektedir.

\section{İstisnai Memur}

657 sayılı devlet memurları kanunun 59 maddesine sıralanan memurluk şeklidir. Aynı kanunun 48. maddesinde belirtilen genel şartları uygun kişiler arasından hiçbir sinav şartı aranmaksızın açıktan ve ya naklen atama yapılabilmektedir. Ayrıca 59. maddede belirtilen atama usulüyle "dışişleri bakanllğı hukuk müşavirlikleri ile devlet konservatuvarında görevlendirilecek uluslararası ün yapmış üstün yeteneklere sahip devlet sanatçıları, olimpiyat şampiyonluğu veya olimpik spor dallarından birinde büyükler kategorisinde birden fazla dünya şampiyonluğu kazananlar arasından spor müşavirleri istisnai memur olarak atanabilmektedirler $(657$ Devlet Memurlupu Kanunu, Md. 59).

Belediyelerde de bu usulle atama yapılabilmektedir. Ancak İçişleri Bakanlığı mahalli idareler genel müdürlüğunün 03.06.2009 gün ve 2009/50 sayılı genelgesi ile böyle bir atama durumunda İçişleri Bakanlığından izin alması gerektiği ve bir seçim döneminde birden fazla atama yapılmaması karara bağlanmıştır. Güngör (2014); 657 sayılı kanunu 58 maddesine göre memur atamalarını yetkili amirlerin yapabileceğini 5393 sayll belediye kanununun 38. maddesinde ve 49. maddesine göre bu tip bir atamada belediye başkanının yetkili kılındığını belirtmektedir. Yine Güngör (2014)'e göre mevzuat İçişleri Bakanlığı’na kanunun yerine getirilmesi konusunda genelge çıkartma yetkisi dışında bir yetki vermemektedir. Ayrıca danıştay idari davalar genel kurulunun bununla ilgili almış olduğu bir iptal kararından da bahsederek ortada bir yetki gaspı olduğunu belirtmektedir. Buna göre de herhangi bir izine tabi olmaksızın bu kadroya atamanın belediye başkanınca yapılabileceği söylenmektedir.

\section{Sözleşmeli Personel}

Yasa koyucu, 657 numaralı yasanın 4. maddesi b bendinde işaret edilen sözleşmeli personeli tanımlarken yapılan sözleşmenin mali yılla sınırlı sözleşme ile çalıştırılan ve işçi sayılmayan kamu görevlisi olarak ifade etmektedir. Aynı maddede kimlerin sözleşmeli çalışturılabileceği de ayrıca belirtilmiştir. Buna göre, kalkınma planı, yıllık program ve iş programlarında yer alan önemli projelerin hazırlanması, gerçekleştirilmesi, işletilmesi ve işlerliği için şart olan, zaruri ve istisnai hallere münhasır olmak üzere özel bir meslek bilgisine ve ihtisasına sahip kişilere ihtiyaç duyulması durumunda Cumhurbaşkanı'nca belirlenen esas ve usuller çerçevesinde ortaya çıkarılan pozisyonlara görevlendirilebilirler (657 sayılı Devlet Memurları Kanunu) 
Dinç, F., Çolakoğlu, T., \& Kurtipek, S. (2018). Büyükşehir belediyelerinin spor hizmetlerinde çalışmakta olan personelin kadro tanımları ve istihdam problemlerine yönelik derleme bir çalışma. Journal of Human Sciences, 15(4), 25332552. doi:10.14687/ihs.v15i4.5616

Akdi olarak istihdam edilen sözleşmeli personel için esas olan yönetimle ile arasındaki idari hizmet sözleşmesidir. Ana istihdam şekli memurluk olan komu teşkilatlarında sözleşmeli personel istihdamı zorunlu hallerde geçici işler için uygulanabilen istisnai bir biçimdir. Bu durum 1982 Anayasası'nın 128. maddesi ile çerçevelenmiştir. Devlet Memurları Kanununun 4 / B maddesi ile tanımlanan sözleşmeli personel, yasanın çıktığ1 1965 yllından bu yana sürekli değişikliğe uğramıştır. $\mathrm{Bu}$ değişikliler neticesinde istisnai bir istihdam biçiminden çıkmıştır. Yasaya göre, özel meslek bilgisine sahip kişiler, zorunlu durumlarda yıllık program, iş programları ve kalkınma planlarının gerçekleşebilmesi için sözleşmeli personel şeklinde istihdam edilebilmektedir. İşçi sayılmayan ve sözleşmeleri mali yılla sinırlı olan kamu görevlileridir (Aslan, 2014, s.17). Pozisyonları Cumhurbaşkanı tarafindan belirlenen esas ve usuller çerçevesinde belirlenir (657 sayıll Devlet Memurlarl Kanunu, Md. 4/B).

\section{Geçici Personel}

Kanunda sayılan istihdam biçimlerinden biri ise geçici personeldir. Sözleşme ile istihdam edilir ve 657 sayılı Devlet Memurları Kanunu'nun 4/C maddesi temel yasal dayanağıdır. Kamuoyunda 4/C’li olarak adlandırlan bu istihdam biçimi bakanlar kurulunca karar alınan görevlerde belirlenmiş sayıda ve ücret sınırı içerisinde sözleşmeye çalışan işçi olmayan kişileri tanımlamaydı (Aslan, 2014, s. 18). Ancak 20.11.2017 yılında çıkarılan ve kamuoyunda taşeron yasası olarak bilinen 696 sayılı Kanun Hükmünde Kararnamenin 17. maddesiyle 657 sayılı devlet memurluğu kanunun 4. maddesinin $\mathrm{c}$ bendi kaldırılmışır. Bu sebeple kanunda belirtilen 4 tip istihdam biçimi çıkarllan 696 sayll Kanun Hükmünde Kararname sonucunda 3 tip istihdam biçimine dönüşmüştür.

\section{İşçi}

Kamu personel rejiminde sözleşmeye dayalı çalıştırılan, yardımcılar kategorisi içerisinde yer alan istihdam biçimidir. İş kanununa bağlı biçimde çalıştırlır. Kamu teşkilatında istihdam edilen işçiler kanuna göre sürekli işçiler ve geçici işçiler şeklinde ikiye ayrilır (Aslan, 2014, s.18).

657 Devlet Memuru Kanununun 4. maddesinin d bendinde bahsedilen işçi, belirsiz süreli sözleşmeyle çalışan sürekli işçi ve altı aydan az süre ile çalıştırlan, sözleşmesinde çalışma süresi belirlenmiş işçi ise geçici işçi olarak tanımlanmaktadır. Bu kanunun a bendinde yer alan memur ve $b$ bendinde yer alan sözleşmeli personel dışında kalan, bu kanunun hükümlerinin uygulanmadığ1 sürekli işçi kadrolarıdır (657 sayılı Devlet Memurları Kanunu, Md. 4).

Belediye ve Bağlı Kuruluşları İle Mahalli İdare Birlikleri Norm Kadro İlke ve Standartlarına Dair Yönetmeliğin Ek-1 tasnif cetvellerinde (II) sayılı kütük olan Belediye ve Bağlı Kuruluşları İle Mahalli İdare Birlikleri İşçi Kadro Kütüğü ile sürekli işçi unvan kodu ve kadro unvanları aşağıdaki şekilde sıralanmıştur.

Tablo 5. Belediye ve Bağlı Kuruluşları İle Mahalli İdare Birlikleri Sürekli İşçi Kadro Kütüğü

\begin{tabular}{ll}
\hline Sürekli İşçi Unvan Kodu & Sürekli İşçi Kadro Unvan1 \\
\hline 25700 & Ustabaşı \\
\hline 25560 & Usta \\
\hline 10820 & Isşçi \\
\hline 1160 & Aşç1 \\
\hline 17840 & Operatör \\
\hline 26320 & Yağc1 \\
\hline 22580 & Şoför \\
\hline 24080 & Temizlik İşçisi \\
\hline
\end{tabular}

(Belediye ve Bağli Kuruluşlari Ile Mahalli Idare Birlikleri Norm Kadro Ilke ve Standartlarina Dair Yönetmelik Ek-1) 
Dinç, F., Çolakoğlu, T., \& Kurtipek, S. (2018). Büyükşehir belediyelerinin spor hizmetlerinde çalışmakta olan personelin kadro tanımları ve istihdam problemlerine yönelik derleme bir çalışma. Journal of Human Sciences, 15(4), 25332552. doi:10.14687/ihs.v15i4.5616

\section{Norm Kadro}

Kural, ilke, örnek tip gibi anlamlara gelen norm kelimesi ve kamu hizmetlerinin devamlı ve düzenli bir şekilde yürütecek kişi anlamına gelen kadro kelimesinin bir araya getirilmesiyle oluşmuş bir terimdir. Kurumun kuruluş amaçlanını gerçekleştirmek için yürütülecek işi üstlenecek en uygun sayı ve nitelikteki çalışma yeridir. Kamu teşkilatının yapı taşıdır. Ürün ve hizmet üretiminde ihtiyaç duyulan en uygun sayı, unvan ve nitelikteki personel kadrosunu belirler (Bilgin, 2007).

Norm kadro iş analizi, iş etüdü, metot etüdü, iş ölçümü ve norm kadro kilavuzu konularında yapılacak önemli çalısmaların sonucunda ortaya çıkar. Bilimsel ve araştırma çalışmasıdır. Teşkilatla ilgili analizler ve buna bağlı olarak teşkilat şeması hazırlanmalı, bu şemadaki tüm pozisyonların tanımları yapılmalıdır. Şemadaki tüm birimlerde yapılan iş ölçümleri ışı̆̆ında istihdam şekline göre görev tanımları ve sayı ve pozisyonlarını gösteren bir norm kadro kılavuzu oluşturulmalıdır (Tamer, 2007, s. 36).

5393 sayılı belediye kanunun norm kadro ve personel istihdamı başlı̆̆1 altındaki 49 . maddesinde "Norm kadro ilke ve standartlarının İçişleri Bakanlığı ve Devlet Personel Başkanlığ1 tarafindan müştereken belirleneceği” ifade edilmiştir. Buna göre "belediyenin ve bağlı kuruluşlarının norm kadroları, bu ilke ve standartlar çerçevesinde belediye meclisi kararyyla" belirlenmektedir. Belediye personeli, belediye başkanı tarafindan atanır. Birim müdürlüğ̈ ve üstü yönetici kadrolarına yapilan atamalar ilk toplantıda belediye meclisinin bilgisine sunulur. Burada norm kadro ile ilgili çeşitli hükümler bulunmaktadır ancak en dikkat çekicisi istihdamda belediye yönetimini sınırlandıran şu ifade olsa gerektir. Belediyenin ylllık toplam personel giderleri, gerçekleşen en son yll bütçe gelirlerinin 213 sayılı Vergi Usul Kanununa göre belirlenecek yeniden değerleme katsayısı ile çarpımı sonucu bulunacak miktarın yüzde otuzunu aşamaz (5393 sayılı Belediye Kanunu, Md. 49).

22.02.2007 ve 26442 sayılı Resmi Gazetede yayınlanan Belediye ve Bă̆lı Kuruluşları İle Mahalli İdare Birlikleri Norm Kadro İlke ve Standartlarına Dair Yönetmeliğin Ek-1’inde yer alan Belediye ve Bağlı Kuruluşları İle Mahalli İdare Birlikleri Tasnif Cetvelleri başlı̆̆ altında çeşitli tasnifler listelenmiştir. Nüfusa göre tasnif edilen belediyelerden A Grubuna giren Büyükşehir Belediyelerin Norm Kadro cetveli aşağıdaki gibidir.

Tablo 6. (A) Grubu: Büyükşehir Belediyeleri Norm Kadro Standartlanı Cetveli

\begin{tabular}{|c|c|c|c|c|c|c|}
\hline Kadro Tanımı & Grup A-1 & Grup A-2 & Grup A-3 & Grup A-4 & Grup A-5 & Grup A-6 \\
\hline & Adet & Adet & Adet & Adet & Adet & Adet \\
\hline Genel Sekreter & 1 & 1 & 1 & 1 & 1 & 1 \\
\hline Genel Sekreter Yardımcısı & 4 & 4 & 4 & 5 & 5 & 7 \\
\hline Teftiş Kurulu Başkanı & 1 & 1 & 1 & 1 & 1 & 1 \\
\hline $\begin{array}{l}\text { Çevre Koruma ve Kontrol Dairesi } \\
\text { Başkanı }\end{array}$ & 1 & 1 & 1 & 1 & 1 & 1 \\
\hline Fen İşleri Dairesi Başkanı & 1 & 1 & 1 & 1 & 1 & 1 \\
\hline Mali Hizmetler Dairesi Başkanı & 1 & 1 & 1 & 1 & 1 & 1 \\
\hline İmar ve Şehircilik Dairesi Başkanı & 1 & 1 & 1 & 1 & 1 & 1 \\
\hline İtfaiye Dairesi Başkanı & 1 & 1 & 1 & 1 & 1 & 1 \\
\hline Zabıta Dairesi Başkanı & 1 & 1 & 1 & 1 & 1 & 1 \\
\hline $\begin{array}{l}\text { İnsan Kaynakları ve Eğitim Dairesi } \\
\text { Başkanı }\end{array}$ & 1 & 1 & 1 & 1 & 1 & 1 \\
\hline Bilgi İşlem Dairesi Başkanı & 1 & 1 & 1 & 1 & 1 & 1 \\
\hline Destek Hizmetleri Dairesi Başkanı & 1 & 1 & 1 & 1 & 1 & 1 \\
\hline Diğer Daire Başkanları(*) & 17 & 20 & 23 & 29 & 35 & 41 \\
\hline 1. Hukuk Müşaviri & 1 & 1 & 1 & 1 & 1 & 1 \\
\hline Hukuk Müşaviri & 2 & 3 & 4 & 6 & 8 & 12 \\
\hline Avukat & 13 & 19 & 25 & 60 & 70 & 160 \\
\hline Özel Kalem Müdürü & 1 & 1 & 1 & 1 & 1 & 1 \\
\hline Şube Müdürü & 70 & 110 & 150 & 180 & 210 & 240 \\
\hline Uzman & 12 & 15 & 18 & 21 & 24 & 30 \\
\hline Şef & 140 & 220 & 300 & 360 & 420 & 480 \\
\hline
\end{tabular}


Dinç, F., Çolakoğlu, T., \& Kurtipek, S. (2018). Büyükşehir belediyelerinin spor hizmetlerinde çalışmakta olan personelin kadro tanımları ve istihdam problemlerine yönelik derleme bir çalışma. Journal of Human Sciences, 15(4), 25332552. doi:10.14687/ihs.v15i4.5616

\begin{tabular}{lllllll}
\hline Müfettiş & 10 & 15 & 18 & 21 & 24 & 45 \\
\hline Müfettiş Yardımcısı & 5 & 5 & 6 & 7 & 8 & 15 \\
\hline Mali Hizmetler Uzmanı & 8 & 8 & 10 & 12 & 14 & 16 \\
\hline Mali Hizmetler Uzman Yardımcısı & 2 & 4 & 5 & 6 & 7 & 8 \\
\hline İdari Personel(**) & 425 & 850 & 1275 & 1500 & 1725 & 3075 \\
\hline Teknik Personel(**) & 425 & 850 & 1275 & 1500 & 1725 & 5175 \\
\hline Sağlık Personeli(**) & 60 & 110 & 160 & 190 & 220 & 310 \\
\hline Yardımcı Hizmet Personeli(**) & 50 & 100 & 150 & 180 & 210 & 270 \\
\hline İtfaiye Şube Müdürü & 5 & 6 & 7 & 9 & 10 & 18 \\
\hline İtfaiye Amiri & 15 & 18 & 21 & 45 & 50 & 180 \\
\hline İtfaiye Çavuşu & 45 & 54 & 63 & 135 & 150 & 540 \\
\hline İtfaiye Eri & 360 & 432 & 504 & 1350 & 1500 & 5400 \\
\hline Zabita Şube Müdürü & 5 & 7 & 8 & 10 & 12 & 14 \\
\hline Zabita Amiri & 15 & 21 & 24 & 50 & 60 & 140 \\
\hline Zabita Komiseri & 45 & 63 & 72 & 150 & 180 & 420 \\
\hline Zabita Memuru & 225 & 315 & 360 & 750 & 900 & 2520 \\
\hline Memur Kadroları Toplam1 & 1971 & 3262 & 4495 & 6589 & 7580 & 19129 \\
\hline Sürekli İşçi Kadroları Toplamı & 985 & 1630 & 2247 & 3294 & 3790 & 9564 \\
\hline (Belediye ve Bă̆li Kurut
\end{tabular}

(Belediye ve Bağli Kuruluşlari Ile Mahalli Idare Birlikleri Norm Kadro Ilke ve Standartlarina Dair Yönetmelik Ek-1)

Tablo 6. verilen listede A grubu (Grup A-1, Grup A-2, Grup A-3, Grup A-4, Grup A-5, Grup A-6) olarak nüfus sayısına tasnif edilmiş büyükşsehir belediyelerin norm kadro tanımları ve adetleri verilmektedir. Burada isimleri zikredilen daire başkanlıkları kurulması zorunlu olan daire başkanlıklarıyken diğer daire başkanlıkları olarak işaretlenen ve sayısı belirlenmiş daire başkanları ise şehrin ihtiyaçlarına binaen belediye meclisince kurulabilecek daire başkanlıklarıdır. Bunların hangileri olduğu ise Belediye ve Bağlı Kuruluşları İle Mahalli İdare Birlikleri Tasnif Cetvellerinin (I) sayılı listesinde sıralanmıştır. Gençlik ve Spor Hizmetleri Daire Başkanlığının kurulması (I) listesinde gösterilmiş, dolayısıyla kurulması zorunlu daire başkanlıkları arasında yer bulamamış ancak belediye meclisince alınacak karar doğrultusunda kurulabilecek daire başkanlıkları olarak yer bulmaktadır. Geniş hizmet alanı ve Anayasanın yüklediği sorumluluğun önemi dikkate alındığında A2 listesinde sıralanan kurulması zorunlu kılınmış 9 adet daire başkanlığının yanında yer alması gerektiği düşünülmektedir.

Bununla birlikte spor hizmetlerinde çalıstırılacak personel niteliklerinden birisi olan antrenörler, (IV) listesine göre idari personel kadrosu olarak tanımlanmaktadır. Buna göre antrenör bir idari personeldir. Oysa antrenörlerin aldıkları eğitim ve uyguladıkları metotlar, ağırlıkla nicel verileri içerisinde barındıran ve uzmanlık gerektiren, hassas ve teknik işlerdendir. Ayrıca sporun temel görevlerinden birisi insan ve toplum sağlığı olduğu herkesçe kabul edilmektedir. Üretilen işin neticesinde antrenman uygulanan birey ya da grubun sağlıklı bir yaşam sürmesini sağlayacak aktiviteler bulunmaktadır. Önleyici sağllk aktiviteleri olarak da değerlendirilebilecek spor faaliyetlerinin yürütücüsü ve planlayıcısı olan Antrenörlerin meslek karşıllı̆ı mevcut şartlarda yetersiz görülmektedir. Buna göre teknik personel ya da sağlık personeli karolarında yer almaları gerektiği düşünülmektedir.

Belediye ve Bağlı Kuruluşları İle Mahalli İdare Birlikleri Norm Kadro İlke ve Standartlarına Dair Yönetmeliğin Ek-1'inde yer alan (IV- V- VI-VII) Sayll Listeler aşağıdaki şekilde gösterilmektedir. 
Dinç, F., Çolakoğlu, T., \& Kurtipek, S. (2018). Büyükşehir belediyelerinin spor hizmetlerinde çalışmakta olan personelin kadro tanımları ve istihdam problemlerine yönelik derleme bir çalışma. Journal of Human Sciences, 15(4), 25332552. doi: $10.14687 /$ ihs.v15i4.5616

Tablo 7. Belediyede İstihdam Edilen Personel Kadro Unvanlar1

\begin{tabular}{|c|c|c|c|}
\hline $\begin{array}{l}\text { İdari Personel Kadro } \\
\text { Unvanlar1 (Iv) }\end{array}$ & $\begin{array}{l}\text { Teknik Personel } \\
\text { Kadro Unvanları (V) }\end{array}$ & $\begin{array}{l}\text { Sağlık Personeli } \\
\text { Kadro Unvanları (V1) }\end{array}$ & $\begin{array}{l}\text { Yardımc1 Hizmet Personeli } \\
\text { Kadro Unvanları (V11) }\end{array}$ \\
\hline Anbar Memuru & Sanat Tarihçisi & Antropolog & Aşç1 \\
\hline Antrenör & Arkeolog & Bakteriolog & Bahçivan \\
\hline Ayniyat Saymanı & Dekoratör & Başhemşire & Bak1c1 Anne \\
\hline Ayniyat Memuru & Desinatör & Baştabip & Bekçi \\
\hline Balık Adam & Ekonomist & Baştabip Yardımcısı & Çocuk Bakıcıs1 \\
\hline Bando Şefi & Ev Ekonomisti & Biolog & Dağgtıc1 \\
\hline Bandocu & Fizikçi & Çocuk Gelişimcisi & Gassal \\
\hline $\begin{array}{ll}\text { Belediye } & \text { Trafik } \\
\text { Memuru } & \\
\end{array}$ & Grafiker & Diş Protez Teknisyeni & Gemici \\
\hline Bilet Satış Memuru & Heykeltraş & Diş Tabibi & Hastabakıc1 \\
\hline Bilgisayar İşletmeni & Hidrobiyolog & Diyetisyen & Hayvan Bakıcıs1 \\
\hline Çocuk Eğiticisi & Hidrolog & Ebe & Hayvan Kesicisi \\
\hline Çocuk Eğitimcisi & İstatistikçi & Eczac1 & Hizmetli \\
\hline $\begin{array}{l}\text { Çocuk Rehberi ve } \\
\text { Gözetimcisi }\end{array}$ & Jeofizikçi & Fizikoterapist & Kaloriferci \\
\hline Dalg1ç & Jeolog & Fizyoterapist & Matbaac1 \\
\hline Eğitmen & Jeomorfolog & Hemşire & Sağlık Teknisyen Yardımcısı \\
\hline Evlendirme Memuru & Kaptan & Kimyager & Teknisyen Yardımcısı \\
\hline Fotoğrafç1 & Kimyager & Laborant & Temizlik Hizmetlisi \\
\hline Gemi Adam1 & Laborant & Odyolog & \\
\hline Gişe Memuru & Matematikçi & Pedagog & \\
\hline İmam & Mimar & Psikolog & \\
\hline Kameraman & Mühendis & Radyoterapist & \\
\hline Memur & Ölçü ve Ayar Memuru & Sağlık Fizikçisi & \\
\hline Muhasebeci & Paleontolog & Sağlik Memuru & \\
\hline Mutemet & Pilot & Sağlık Teknikeri & \\
\hline Mütercim & Ressam & Sağlık Teknisyeni & \\
\hline Sayaç Memuru & Restoratör & Sosyal Çalışmacı & \\
\hline Sivil Savunma Uzmanı & Şehir Plancıs1 & Sosyal Hizmet Uzman1 & \\
\hline Şoför & Teknik Ressam & Tabip & \\
\hline Tahsildar & Tekniker & Tibbi Teknolog & \\
\hline Tercüman & Teknisyen & Uzman Tabip & \\
\hline $\begin{array}{lrl}\text { Veri Hazırlama } & \text { ve } \\
\text { Kontrol İşletmeni } & \\
\end{array}$ & Topograf & $\begin{array}{l}\text { Uzman (Tab. Uz. Tüz. } \\
\text { Göre) }\end{array}$ & \\
\hline & Peyzaj Mimar1 & Veteriner Hekim & \\
\hline \multirow[t]{4}{*}{ Veznedar } & Kütüphaneci & $\begin{array}{l}\text { Veteriner } \\
\text { Teknikeri }\end{array}$ & \\
\hline & Çözümleyici & $\begin{array}{l}\text { Veteriner } \\
\text { Teknisyeni }\end{array}$ & \\
\hline & Programc1 & & \\
\hline & Sosyolog & & \\
\hline
\end{tabular}

(Belediye ve Bağli Kuruluşlari Ile Mahalli Idare Birlikleri Norm Kadro Ilke ve Standartlarina Dair Yönetmelik Ek-1)

Tablo 7'de yer alan kadro unvanlar1 belediyelerde istihdam edilebilecek kadrolar1 tanımlamaktadır. Buna göre spor hizmetleri ile ilgili idari personel kısmında 6550 unvan kodu ile Antrenör ve yine aynı kısımda 9880 unvan kodu ile eğitmen olarak beden eğitimi öğretmenleri çalıştırılabilmektedir. 
Dinç, F., Çolakoğlu, T., \& Kurtipek, S. (2018). Büyükșehir belediyelerinin spor hizmetlerinde çalışmakta olan personelin kadro tanımları ve istihdam problemlerine yönelik derleme bir çalışma. Journal of Human Sciences, 15(4), 25332552. doi:10.14687/ihs.v15i4.5616

\section{Sonuç}

Genel olarak spor ile ilgili işlerin yürütülmesi özel ihtisas isteyen konulardır. Ülkemizde beden eğitimi ve spor alanlarında oluşan personel ihtiyacının karşılanması için nitelikli elaman yetiştiren beden eğitimi ve spor yüksekokulları ve spor bilimleri fakülteleri 1990’lı yılların ikinci yarısından itibaren 4 ihtisas bölümüne ayrılan eğitim ve öğretim müfredatı uygulamaktadır. 2000’li yılların başlarından itibaren mezunlar vermeye başlayan bu 4 bölüm; Beden Eğitimi Öğretmenliği, Spor Yöneticiliği, Antrenörlük ve Rekreasyon bölümleridir. Bu güne kadar binlerce mezun veren bu okulların eğitim ve öğretim müfredatları ihtiyaçlara göre ve akademik çalışmalar ışı̆̆ında geliştirilerek günümüze ulaşmışır. Bu bölümlerden mezun olan kişiler kamu kurumlannda görev alabilmek için 657 sayılı Devlet Memuru Kanunun emrettiği şartları yerine getirmek durumundadır. Buna göre ÖSYM eliyle gerçekleştirilen KPSS sınavlarından elde ettikleri başarı sırasına göre kamu görevlerine yerleştirilmektedirler. Ancak konu belediyeler ve büyükşehir belediyelerinde istihdama geldiğinde bu alanlardan mezun olan kişiler mezuniyet unvanlarının karşıllı̆ını görememektedirler. Belediyelerde kadro düzenlemeleri 5393 Sayılı Belediye Kanununun 49. maddesi uyarınca gerçekleşebilmektedir. Burada yer alan norm kadro ve personel istihdamı başlı̆̆ altında sayılan kadrolar arasında Spor Yöneticisi, Antrenör, Rekreasyon Uzmanı ve Beden Eğitimi Öğretmeni yer almamaktadır. Belediyelerin devlet memurları kadroları arasında yer bulamayan sporla ilgili bu kadro tanımlarında yalnızca Antrenörler, Belediye ve Bağlı Kuruluşları İle Mahalli İdare Birlikleri Norm Kadro İlke ve Standartlarına Dair Yönetmeliğin Ek-1 Belediye ve Bağlı Kuruluşları İle Mahalli İdare Birlikleri Tasnif Cetvellerinde İdari Personel Kadro Unvanları olarak sayılmaktadır. Oysa Sevim’e (2006) göre antrenörlük teknik bir iştir ve antrenörler teknisyendir. Ülkemizde spor alanında eğitim ve öğretim veren kurumların Beden Eğitimi Öğretmenliği, Spor Yöneticiliği, Antrenörlük ve Rekreasyon bölümlerinde birbirine yakın bir müfredat işlenmektedir. Spor Bilimleri temel eğitimleri içiren bu müfredattan mezun olan antrenörleri teknisyen olarak kabul edildiğine göre diğer bölüm mezunları da bu sınıfta değerlendirilebilecektir. Okulların bahse konu bu bölümlerinden mezun olanlar genel olarak teknik donanıma sahip olabilmektedirler.

28077 sayı ve 2011 tarihli Resmi Gazete yayınlanan yönetmeliğin 6. maddesi (b) bendine göre, beden eğitimi ve spor yüksekokullarından mezun olanlar gençlik ve spor uzman veya uzman yardımcısı olarak gençlik ve spor bakanlığında görev alabilmektedirler (Gençlik ve Spor Uzman ve Uzman Yardımcilığı Sınav, Atama, Yetiştirilme, Görev ve Çalışma Usul ve Esasları Hakkında Yönetmelik, 2018, Md. 6/b). 3 Haziran 2011 de yayınlanan 638 sayılı Gençlik ve Spor Bakanlığının Teşkilat ve Görevleri Hakkında Kanun Hükmünde Kararnamenin 27. maddesine göre; "Bakanlık, görev alanına giren konularda çalıştrılmak üzere Gençlik ve Spor Uzmanı ile Gençlik ve Spor Uzman Yardımcısı istihdam eder". Ayrıca Gençlik ve Spor Bakanlığ1 Spor Faaliyetleri Dairesi Başkanlığınca yayınlanan Spor Genel Müdürlüğü Spor Faaliyetleri Dairesi Başkanlığ Görev, Yetki Ve Sorumlulukları Talimatının 13 ve 14. maddelerinde sportif eğitim uzmanları ve spor uzmanlarının yetki ve sorumlulukları tanımlanmıştır. Bu durum aşağıda tablolar şeklinde gösterilmiştir.

Tablo 8. Sportif Eğitim Uzmanlarının görev, yetki ve sorumlulukları

a) Başkanın talimatı ve dairenin görev yetki ve sorumlulukları dâhilinde spor eğitimine ilişkin kısa, orta ve uzun vadeli plan ve programlar hazırlamak ve Bașkana sunmak.

b) Uzmanlık alanı ile ilgili konularda yeni projeler üretmek.

c) Spor Eğitimine ilişkin ülkemizde ve uluslararası alandaki gelişmeleri takip etmek.

ç) Şube müdürlükleri ile hizmetin önemi ve gereğine göre koordinasyon ve işbirliği yapmak.

d) Daire Başkanı tarafindan verilecek benzeri görevleri yapmak.

(Gençlik ve Spor Bakanlığı Spor Faaliyetleri Dairesi Başkanlığı, 2018, Md. 13) 
Dinç, F., Çolakoğlu, T., \& Kurtipek, S. (2018). Büyükşehir belediyelerinin spor hizmetlerinde çalışmakta olan personelin kadro tanımları ve istihdam problemlerine yönelik derleme bir çalışma. Journal of Human Sciences, 15(4), 25332552. doi: $10.14687 /$ ihs.v15i4.5616

Tablo 9. Spor Uzmanlarının görev, yetki ve sorumlulukları

a) Daire Başkanlı̆̆ının hizmetlerinin yürütülmesinde sürat ve verimliliği artırmak, yeni hizmet teklifleri geliştirmek amacıyla araştırma ve incelemeler yapmak ve bir raporla Başkanlığa sunmak.

b) Uzmanlık alanılla ilgili çeşitli teknik ve idari toplantılara katılmak ve kendisine verilen yetki sınırları içinde Başkanlığı temsil etmek

c) Görevlendirildiği araştırma ve çalışmaların uygulanmasını izlemek ve çıkacak sorunlar konusunda gerekli tedbirleri geliştirerek sonuçlandırılmasını sağlamak.

d) Görev alanına giren konularda periyodik raporlar ve yeni hizmetlerin başlatılması için teklifler hazırlamak ve ön çalışmalar yapmak.

e) Uygulamaya konulmuş faaliyetlerin tespit edilmiş politikalar, programlar, planlar ve prensipler ile Genel Müdürlüğün amacina uygun olarak yürütülmesini izlemek ve gerekirse bu konuda araştırmalar yaparak Daire Başkanlığına teklifte bulunmak.

f) Eğitim programlarında eğiticilik görevi yapmak.

g) Daire Başkanı tarafindan verilecek benzeri görevleri yapmak.

(Gençlik ve Spor Bakanlığı Spor Faaliyetleri Dairesi Başkanlığı, 2018, Md. 14)

Aşağıda KPSS sınavı sonucunda Spor alanlarından mezun olanların çeşitli kurumlara atanabilmeleri için gerekli olan nitelikler ve mezuniyet alanları verilmektedir.

Tablo 10. Lisans Mezunları İçin Aranan Nitelikler

\begin{tabular}{|c|c|c|c|}
\hline \multirow{2}{*}{ Nitelik Kodu } & \multirow{2}{*}{ Öğrenim Koşulu } & \multicolumn{2}{|c|}{ Mezuniyet Alanı Kodları } \\
\hline & & Nit1 & Nit2 \\
\hline 4409 & $\begin{array}{l}\text { Spor Bilimleri, Spor Bilimleri ve Teknolojisi Lisans } \\
\text { Programlarınn Birinden Mezun Olmak. }\end{array}$ & 7219 & 8256 \\
\hline 4411 & $\begin{array}{l}\text { Antrenörlük Eğitimi Lisans Programından Mezun } \\
\text { Olmak. }\end{array}$ & 7101 & \\
\hline 4413 & $\begin{array}{l}\text { Spor Yöneticiliği veya Spor } \text { Yönetimi } \\
\text { Programindan Mezun Olmak. }\end{array}$ & 7104 & 9176 \\
\hline 4415 & $\begin{array}{l}\text { Beden Eğitimi ve Spor Lisans Programından Mezun } \\
\text { Olmak. }\end{array}$ & 8123 & \\
\hline 4416 & $\begin{array}{l}\text { Beden Eğitimi Öğretmenliği Lisans Programından } \\
\text { Mezun Olmak. }\end{array}$ & 8307 & \\
\hline 4417 & $\begin{array}{l}\text { Beden Eğitimi ve Spor } \\
\text { Programı̆ndan Metmenliği }\end{array}$ & 7102 & \\
\hline 4399 & $\begin{array}{l}\text { Rekreasyon, Rekreasyon } \\
\text { Programindan Mezun Olmak. }\end{array}$ & 7103 & 9172 \\
\hline
\end{tabular}

(Ölçme, Seçme ve Yerleştirme Merkezi Başkanllğı, 2018)

Tablo 11. Mezun Olunacak/Olunan Lisans Programı

\begin{tabular}{|c|c|}
\hline Nitelik Kodu & Mezun Olunacak/Olunan Lisans Programı \\
\hline 7219 & Spor Bilimleri \\
\hline 8256 & Spor Bilimleri ve Teknolojisi \\
\hline 7104 & Spor Yöneticiliği \\
\hline 9176 & Spor Yönetimi \\
\hline 8307 & Beden Ĕ̈itimi Öğretmenliği \\
\hline 7102 & Beden Eğitimi ve Spor Öğretmenliği \\
\hline 8123 & Beden Eğitimi ve Spor Yüksekokulu \\
\hline 9447 & Engellilerde Beden Eğitimi ve Spor Öğretmenliği \\
\hline 9265 & Engellilerde Egzersiz ve Spor Eğitimi \\
\hline 7101 & Antrenörlük Eğitimi \\
\hline 7103 & Rekreasyon \\
\hline 9172 & Rekreasyon Yönetimi \\
\hline
\end{tabular}

(Ölçme, Seçme ve Yerleştirme Merkezi Başkanlığ1, 2018) 
Dinç, F., Çolakoğlu, T., \& Kurtipek, S. (2018). Büyükşehir belediyelerinin spor hizmetlerinde çalışmakta olan personelin kadro tanımları ve istihdam problemlerine yönelik derleme bir çalışma. Journal of Human Sciences, 15(4), 25332552. doi:10.14687/ihs.v15i4.5616

Yukarıda belirtilen alanlardan mezun olanların Gençlik ve Spor Bakanlığı'nda gençlik ve spor uzmanı, gençlik ve spor uzman yardımcısı, spor uzmanı ve sportif eğitim uzmanı gibi görevlere atamaları yapılabilirken belediyelerde istihdam edilememeleri büyük bir eksiklik olarak düşünülebilecektir.

Belediyelerin personelle ilgili, planlama ve motivasyon eksikliği, performans ölçme ve değerlendirmedeki problemler, iş analiz ve tanımı, nitelikli personel ve yönetici eksikliği personel yönetiminin ana problemini oluşturmaktadır (Yüksel, F. \&Çevik, O.\&Ardıç, 2008, s. 1-26)."İşs analizi İKY'nin alt yapısını oluşturur" diyen Bingöl (2006) iş analizini tanımlarken personel tedariki ve seçimi, yapılacak işleri tanımlama ve bu tanıma göre personelde bulunması gereken özellikleri belirleme süreci olarak değerlendirmektedir. İş analizi işlerin nasıl yapılacağından çok nasıl yapıldı̆̆ını ayrıntılı biçimde ortaya koymaktadır. Isş analizi süreci sonucunda ortaya çıkan verilerle ihtiyaç duyulan personelin niteliğini ve işe alınma sürecini belirler. Yerel yönetimlerde personel sisteminin önemli bir eksikliğinin personel gücünün planlanmaması olarak gören Walker (1985), personel planlamasının; mevcut durumu tespit ederken, gelecekte ne gibi ihtiyaçların oluşacağını belirlemede çok önemli olduğunu belirtmektedir (Walker'dan aktaran Yüksel, Çevik ve Ardıç, 2008, s. 1-26).

İyi bir yönetim ve iş verimi için iş tanımı yapılmış, kural ve ilkeleri belirlenmiş kadrolar oluşturulması gerektiğini düşünürsek belediyeler bünyesinde spor hizmetlerinde çalıştrilmak üzere kadro ve iş tanımları yapılmasının gerekliliği ortaya çıkmaktadır. Belediyelerde spor hizmetlerinde görevlendirilmek üzere spor yöneticileri, rekreasyon uzmanları ve antrenörlerin teknik personel kadro unvanları arasında tanımlarının yapılması gerektiği düşünülmektedir. Gençlik ve Spor Bakanlı̆̆ bünyesinde çalıştırılabilen sportif eğitim uzmanı ve spor uzmanı ya da gençlik ve spor uzmanı ve gençlik ve spor uzman yardımcısı gibi kadro tanımlarının benzerleri belediyeler için de yapılabilir. 657 sayılı devlet memuru kanununda tanımlanmış bu kadroların kanunda yapılacak değişiklikle belediyelerde istihdamının önü açılabilir. Ayrıca istisnai kadro kapsamında "Devlet Konservatuvarında görevlendirilecek uluslararası ün yapmış üstün yeteneklere sahip olanların" devlet sanatçısı olarak, "olimpiyat şampiyonluğu veya olimpik spor dallarından birinde büyükler kategorisinde birden fazla dünya şampiyonluğu kazananları" spor müşaviri olarak atanabilmektedir. Belediyelerin spor hizmetlerinde çalıstırılacak nitelikli personellerin bu kanun kapsamına alınarak istisnai kadro kapsamında atanabilecekler arasına alınabilmesi sağlanmalıdır.

Belediye kanunu ve büyükşehir belediye kanununda yapılacak değişiklikler ile Belediye ve Bağlı Kuruluşları İle Mahalli İdare Birlikleri Norm Kadro İlke ve Standartlarına Dair Yönetmelikte yapılacak değişikliklerle de spor yöneticisi, antrenör ve rekreasyon uzmanları istihdamı sağlanabilecektir. Bununla birlikte belediyelerin spor hizmetlerinde daha etkin ve verimli çalışmaların yürütülebileceği öngörülebilecektir. Her biri alanında uzmanlaşmış, teknik donanıma sahip bu uzmanlar belediyelerin yapacağı spor hizmetleri yatırımları ve faaliyetleri en etkin biçimde yürütebileceği düşünülebilecektir. Sözleşmeli personel olarak da iş tanımı ve unvan tanımı yapılarak spor işlerinin yürütülmesi amacıyla spor alanlarından mezun bu kişilere alan açılmasının neticelerinin müspet olacağı değerlendirilebilir. Gerek 657 Devlet Memuru Kanunu, gerek belediye kanunu ve gerekse büyükşehir belediye kanununun ilgili maddelerinde en kısa sürede bu doğrultuda yapılabilecek değişikliklerin önemli faydalar sağlayacağı öngörülmektedir.

- Buna göre TBMM de gerekli çalışmalar yapılmalı

- Konuyla ilgili belediye yöneticileri ve spor alanlarında eğitim veren yükseköğretim kurumlarından görüş alınmalı

- Belediyelerde spor hizmetleri alanlarında istihdama yönelik iyileştirici çalışmalar yapilmalıdır

$\mathrm{Bu}$ alanda çalışma yapacak olan bilim insanlarının uluslararası karşılaştırmalar yapabilir, personel mevzuatını daha derinlemesine inceleyerek teknik çalışmalarda bulunabilir, yerel 
Dinç, F., Çolakoğlu, T., \& Kurtipek, S. (2018). Büyükșehir belediyelerinin spor hizmetlerinde çalışmakta olan personelin kadro tanımları ve istihdam problemlerine yönelik derleme bir çalışma. Journal of Human Sciences, 15(4), 25332552. doi:10.14687/ihs.v15i4.5616

yönetimlerin diğer unsurları olan özel idarelerle ilgili benzeri çalışmalar yürütebilir ya da diğer devlet kurumlarıla ilgili spor işlerinin yürütülmesinde istihdam konularında çalısma yapabilirler.

\section{Kaynaklar}

Ardahan, F., (2016). Her Yönüyle Rekreasyon. Ankara: Detay

Aslan, O. E., (2014). Kamu Personel Hukuku. 06.11.2018 tarihinde http://kitap.okur-yazar.net/e kitap/aof/HUK303U-kamu-personel-hukuku.pdf adresinden erişilmiştir.

Belediye Kanunu. (2018). Mevzuat Bilgi Sistemi. 23.10.2018 tarihinde http://www.mevzuat.gov.tr/Metin1.Aspx?MevzuatKod=1.5.5393\&MevzuatIliski=0\&sou ceXmlSearch=belediye $\&$ Tur $=1 \&$ Tertip $=5 \& N o=5393$ adresinden erişilmiştir

Belediye ve Bağlı Kuruluşları İle Mahalli İdare Birlikleri Norm Kadro İlke ve Standartlarına Dair Yönetmelik. (2018). Mevzuat Bilgi Sistemi. 07.11.2018 tarihinde http://www.mevzuat.gov.tr/Metin.Aspx?MevzuatKod=7.5.11125\&Mevzuatlliski=0\&sou ceXmlSearch $=$ mahalli \%20idareler adresinden erişilmiştir.

Bilgin, U. K., (2007). Yerel yönetimlerde Norm Kadro (Belediyeler). A. Subuktay. (Ed.), Yerel Yönetimler Reformu Destekleme Programı Kitabı Dizisi 1 Belediye Yönetimi, Ankara: Sarıyldız

Bingöl, D., (2006). Insan Kaynaklar Yönetimi. İstanbul: Arrkan

Büyükşehir Belediyesi Kanunu. (2018). Mevzuat bilgi sistemi. 21.10.2018 tarihinde http://www.mevzuat.gov.tr/Metin1.Aspx?MevzuatKod=1.5.5216\&MevzuatIliski=0\&sou ceXmlSearch $=\mathrm{b} \% \mathrm{C} 3 \% \mathrm{BCy} \% \mathrm{C} 3 \% \mathrm{BCk} \% \mathrm{C} 5 \% 9$ Fehir $\% 20$ belediye $\&$ Tur $=1 \&$ Tertip $=5 \& \mathrm{~N}$ $=5216$ adresinden erişilmiştir

Demir, K. A., (2017). Cumburiyet Dönemi Belediyecilik. Kanunlar ve Yerel Seçimleri 1923-2014. Ankara: İmaj

Devlet Memurları Kanunu. (2018). Mevzuat Bilgi Sistemi. 16.10.2018 tarihinde http://www.mevzuat.gov.tr/Metin1.Aspx?MevzuatKod=1.5.657\&MevzuatIliski=0\&sour $\mathrm{XmlSearch}=657 \&$ Tur $=1 \&$ Tertip $=5 \& \mathrm{No}=657$ adresinden erişilmiştir.

Devlet Personel Başkanllğ1 internet adresi. (2018). 08.11.2018 tarihinde http://www.dpb.gov.tr/tr tr/daire-baskanliklari/kamu-personel-istihdami-personel-baskanligi/kamu-personel istihdami-dairesi-baskanligi-kamu-personel-istihdam $\% \mathrm{C} 4 \% \mathrm{~B} 1-317 / 657$ say $\% \mathrm{C} 4 \% \mathrm{~B} 11 \% \mathrm{C} 4 \% \mathrm{~B} 1-\mathrm{k} a n u n-m a d d e-4-a-g o r e-\tan \% \mathrm{C} 4 \% \mathrm{~B} 1 \mathrm{~m} \% \mathrm{C} 4 \% \mathrm{~B} 1 \quad$ adresinden erişilmiştir.

Genç, D. A. (1998). Spor Hukuku, İstanbul: Alfa (1)

Gençlik ve Spor Bakanlığı Spor Faaliyetleri Dairesi Başkanllğı internet adresi. (2018). Spor Genel Müdürlügü Spor Faaliyetleri Dairesi Baskanluğ Görev, Yetki Ve Sorumluluklarn Talimatı 08.11.2018 tarihinde http://sgm.gsb.gov.tr/Sayfalar/265/174/spor-faaliyetleri-dairesi-baskanligi.aspx adresinden erişilmiştir.

Gençlik Ve Spor Uzman Ve Uzman Yardımcılığı Sınav, Atama, Yetiştirilme, Görev Ve Çalışma Usul Ve Esasları Hakkında Yönetmelik. (2008). Mevzuat Bilgi Sistemi. 16.11.2018 tarihinde http://www.mevzuat.gov.tr/Metin.Aspx?MevzuatKod=7.5.15366\&Mevzuatlliski=0\&sou ceXmlSearch adresinden erişilmiştir

Güngör, H.(2014). Belediye Teskilat ve Personel İstihdamı. Ankara: Pozitif

İ Özel İdaresi Kanunu. (2018). Mevzuat Bilgi Sistemi. 21.10.2018 tarihinde http://www.mevzuat.gov.tr/Metin1.Aspx?MevzuatKod=1.5.5302\&Mevzuatlliski=0\&sou ceXmlSearch $=5302 \&$ Tur $=1 \&$ Tertip $=5 \& N o=5302$ adresinden erişilmiştir.

Kanunlar Kararlar Daire Başkanlığı.(2015). Türkizye Cumburiyeti Anayasası ve Türkiye Büyük Millet Meclisi İctürzügü. Ankara: TBMM

Karakılçık, Y. (2016). Yeni Yerel-Bölgesel Gelismeler Isı̆ğnnda Yerel Yönetimler. Ankara: Seçkin (3)

Keleş, R. (2012). Yerinden Yönetim ve Siyaset. İstanbul: Cem

Keleş, R., Yavuz, F. (1983). Yerel Yönetimler. Ankara: Turhan 
Dinç, F., Çolakoğlu, T., \& Kurtipek, S. (2018). Büyükșehir belediyelerinin spor hizmetlerinde çalışmakta olan personelin kadro tanımları ve istihdam problemlerine yönelik derleme bir çalışma. Journal of Human Sciences, 15(4), 25332552. doi:10.14687/ihs.v15i4.5616

Konter, E., (1996). Bir Lider Olarak Antrenör. İstanbul: Alfa

Kurtipek, S.,\&Yenel,İ. F. (2018). Türkiye'de Yerel Yönetimler ve Spor. A.Azmi Yetim (Ed.).Yönetim ve Spor (s.429-457). Ankara: Berikan Yayınevi.

Medeni Kanun. (2018). Mevzuat Bilgi sistemi. 16.10.2018 tarihinde http://www.mevzuat.gov.tr/MevzuatMetin/1.5.4721.pdf adresinden erişilmiştir.

On Dört İlde Büyükşehir Belediyesi ve Yirmi Yedi İlçe Kurulması İle Bazı Kanun ve Kanun Hükmünde Kararnamelerde Değişiklik Yapılmasına Dair Kanun. (2018). Mevzuat Bilgi sistemi.

21.10.2018 tarihinde http://www.mevzuat.gov.tr/Metin1.Aspx?MevzuatKod=1.5.6360\&MevzuatIliski=0\&sou ceXmlSearch $=\mathrm{b} \% \mathrm{C} 3 \% \mathrm{BCy} \% \mathrm{C} 3 \% \mathrm{BCk} \% \mathrm{C} 5 \% 9 \mathrm{Fehir} \% 20$ belediye $\&$ Tur $=1 \&$ Tertip $=5 \& \mathrm{~N}$ $=6360$ adresinden erişilmiştir.

Ortaylı, İ.,(1985). Tanżimat’tan Cumburiyete Yerel Yönetim Geleneğg. İstanbul: Hil. 1985

Öktem, M., Parlak, B.(2010). Kurumdan Uygulamaya Yerel Yönetimler Illkeler Yaklaşımlar Ve Mevzuat. Bursa: Alfa (2)

Ölçme, Seçme ve Yerleştirme Merkezi Başkanllğı internet adresi. (2018). 2018 Kamu Personel Seçme Sinavn (Kpss) Kulavuzu (Lisans). 08.11.2018 tarihinde https://dokuman.osym.gov.tr/pdfdokuman/2018/KPSS/KILAVUZ10052018.pdf adresinden erişilmiştir.

Ölçme, Seçme ve Yerleştirme Merkezi Başkanlığı internet adresi. (2018). Lisans Mezunlarn İçin Aranan Nitelikler. $\quad 08.11 .2018$ 08.11.2018 tarihinde https://dokuman.osym.gov.tr/pdfdokuman/2018/KPSS/TERCIH1/NitelikLisans26062 18.pdf adresinden erişilmiştir.

Rekreasyon Çalışmaları ve Araştırmaları Derneği internet adresi. (2016). Rekereasyon Calş̧tayı Tutanaklar. 20.10.2018 tarihinde http://www.rekcad.org/pdf/2.calistayraporu.pdf adresinden erişilmiştir.

Sevim, Y., (2006). Antrenör Eğitimi İlkeleri. Ankara: Nobel

Sunay, H., (2009). Spor Yönetimi. Ankara: Gazi

Şahin, Y.,(2014). Yerel Yönetimler. Bursa: Ekin (1)

Şengül, R.,(2014). Yerel Yönetimler. Kocaeli: Umuttepe (4)

Tamer, M., (2007). Yerel Yönetimlerde Insan Kaynaklar. Ankara: Seçkin.

Tekin, A., (2016). Serbest Zaman Bağlamında Oyun Teorisi. S. Karaküçük (Ed.), Rekreasyon Bilimi (s. 48). Ankara: Gazi.

Toprak, Z., (2006). Yerel Yönetimler. Ankara: Nobel (6)

Tortop, N., (1994). Mahalli İdareler. Ankara: Yarg1 (5)

Türk Dil Kurumu internet adresi. (2018). 16.10.2018 tarihinde http:/ / www.tdk.gov.tr/index.php?option $=$ com gts\&kelime $=$ KADRO adresinden erişilmiştir.

Weber, M., (2012). Ekonomi Ve Toplum (2. Cilt) (L. Boyac1, Çev.). İstanbul: İstanbul.

Yildırım, İ., (2018). Bölüm Başkanmm Mesajı. 20.10.2018 tarihinde http://besyo.aku.edu.tr/rekreasyon bolumu/ adresinden erişilmiştir.

Yücel, A.S., Atalay, A., Korkmaz, M.(2016). Türkizye'de Yerel Yönetimler Ve Spor Hizmetleri. İstanbul: Nobel (1)

Yüksel, F. \& Çevik, O. \& Ardıç, K. (2008). Belediye Başkeanlan Gözüyle Yerel Yönetim Sorunlar. Sosyal Bilimler Araştırmaları Dergisi

Ziyagil, M. A., (2013, Haziran). Sporu Uygulamalarnda Antrenörïn Yeri ve Önemi. Hitit Üniversitesi Çalıştayında sunulmuş bildiri. F. Yamaner, A. Turgut. (Ed.) 
Dinç, F., Çolakoğlu, T., \& Kurtipek, S. (2018). Büyükșehir belediyelerinin spor hizmetlerinde çalışmakta olan personelin kadro tanımları ve istihdam problemlerine yönelik derleme bir çalışma. Journal of Human Sciences, 15(4), 25332552. doi:10.14687/ihs.v15i4.5616

Extended English Summary

In our country, the basic administrative functions of the state are carried out by the general administrative organizations, in particular by the central organization. Although the services are carried out by the central administration, it requires cooperation with local governments in provinces and local provinces. In this context, the state classifies public services and transfers some of its duties, powers and responsibilities to the local administrations from central administrations in order to perform local and joint services at local level. (Kurtipek and Yenel, 2018).

It is known that Municipalities are to be a local government. According to Yücel, Atalay and Korkmaz (2016), new management methods have been developed for the improvement of the needs. These approaches were developed together with the society and formed the local government model. (Yücel, Atalay and Korkmaz, 2016, p. 1).

In Greek the metropolitan is formed the metro (main) and polis (city) of metropolis. In fact, this word was defined by the ancient Greek as city states. Today, in the 19th century, it is possible to reach the highest level of industrialization. Due to the migrations to the city as a result of industrialization, large settlements occurred. The definition of these centers as Metropolitan has become a habit. (From Eke Şahin, Local, 2014, p. 157)

The Metropolitan Municipality Law No. 5216, which is in force today, was enacted on 10 July 2004 and the governance form of the metropolitan municipalities was determined. One of the most important issues in the finalization process is the law numbered 6360 which was adopted in 2012. With the amendment made within the framework of the Law No: 6360 on the Amendment of the Law on Amendments to the Decree Law and Legislative Decree Laws and the Establishment of the Metropolitan Municipality and Twenty-Seven Cities in 14 Provinces, the boundaries of the metropolitan municipalities are defined as the provincial boundary. According to this law, the number of metropolitan municipalities in Turkey has been increased to 30 and the legal status of the metropolitan municipality administration has been regulated. This situation has brought up a new management approach in metropolitan areas. Previously, it was responsible for the coordination of the sub-municipalities (central district municipalities) in the city center. With this new regulation, it was responsible for the coordination of all municipalities within the provincial borders.

In article 59 of the Constitution of the Turkish Republic; "The State takes measures to improve the physical and mental health of Turkish citizens of all ages and encourages the spread of sports to the masses "and defines sports services as a homework. In these terms, the Constitution imposes a responsibility on the conduct of sports services to local governments. In addition, the Law No. 5393 also loads various responsibilities and duties. Article of the Law no 14 (a). Here, the municipalities have been assigned to perform youth or sports services. Article 7 (m) of the Law No. 5216 on the Metropolitan Municipality refers to some tasks related to sports services. These include making facilities and organizing sports competitions between amateur teams. Staff is needed to carry out these tasks and assignments. The staff of the Italian language (quadro), which is a word of the Turkish language institution, has been identified as the following words: All of the tasks of a public institution, an enterprise, supervision or orientation and the tasks, powers and responsibilities carried by them. (Turkish Language Association, 2018).

Public entities established by law in Turkey (5393 Municipalities Law, Art. 3) which municipalities, employ staff are subject to the Constitution and the law. Article 128 of the Constitution provides that public legal entities may carry out public services that they are obliged to conduct by civil servants and other public officials. (Constitution and Rules of Procedure of the Republic of Turkey Grand National Assembly of Turkey, 2015, Art. 128, p. 89) The definition of who is a Civil servant defined in the law 657. 
Dinç, F., Çolakoğlu, T., \& Kurtipek, S. (2018). Büyükşehir belediyelerinin spor hizmetlerinde çalışmakta olan personelin kadro tanımları ve istihdam problemlerine yönelik derleme bir çalışma. Journal of Human Sciences, 15(4), 25332552. doi: $10.14687 /$ ihs.v15i4.5616

Article 4 of Law No. 657 on Civil Servants mentions 4 types of personnel. According to this, public services; civil servants, contracted personnel, temporary personnel and workers. Article 5 of the Law states that institutions subject to this law cannot employ personnel other than the four forms of employment written in the fourth article of the Law. However, with the Article 17 of the Decree Law No. 696, the definition of temporary personnel in sub-clause (C) of Article 4 of the Civil Servants Law No. 657 has been removed. For this reason, it means the 3 forms of employment in force.

The staff operations in municipalities are carried out by Decree Law No. 190 in the past. With the Law on Municipalities numbered 5272, which was enacted in 2004, this authority was given to their councils. According to this, in 2007, the staff operations are carried out according to the Adminastrative Regulation on Municipalities and Affiliated Institutions and the Norm Staff Principles and Standards "issued by the Ministry of Interior and State Personnel Presidency. (Güngör, 2014, p.59).

In order to be a civil servant, persons must have the general conditions specified in Article 48 of the Civil Servants Law of No. 657. In addition, it may be requested by the institutions to be employed to have the special conditions specified in paragraph (b) of Article 48. Turkish citizens and those who have completed the age of 18 may be civil servants. As an exception, those who have completed the age of 15 and who have made themselves to the court with the consent of their parents and with the consent of their parents 21 (Turkish Civil Code No. 4721, Art. 12) and those who have completed a vocational and art school can also serve as civil servants. The civil servants' examinations (KPSS) (successful ones), which meet these requirements and as set out in Article 50, can be appointed as civil servants.

In the classification of civil servants within the scope of Law No. 657 on Civil Servants, the personnel who will carry out the duties of sports services are classified as General Administration Services. However, according to Sevim (2006), Coaching is a technical business and coaches are technicians. (Sevim, 2006, p.9). In this case, Sports Managers and Recreation Specialists, who have passed a cooperative training program and very close to each other, can be accepted as technicians. Therefore, it is considered that people who have completed their education in these fields should be in the Technical Services class in the classification made under the Civil Servants Law No. 657. The characteristics and qualifications of public officials and personnel to be employed in municipalities and where and under which conditions they will be employed; "Municipal and Affiliated Institutions and Local Administration Associations are regulated by the Regulation on Norm Staff Principles and Standards". Only coaches are provided as personnel who will carry out sports services. Trainers are listed among Administrative Staff. As mentioned above, graduates of vocational schools or faculties who are in charge of sports services should be considered as technical personnel and should take their place among the title of Technical Staff. In addition, graduates of these fields, such as Sportive Training Specialist, Sport Expert, Youth and Sports Expert or Youth and Sports Assistant Expert working within the Ministry of Youth and Sports, should be included in the related legislation. 